University of Nebraska - Lincoln

DigitalCommons@University of Nebraska - Lincoln

\title{
Functional Classification of Swine Manure Management Systems Based on Effluent and Gas Emission Characteristics
}

J. A. Zahn

USDA-ARS, zahn@nsric.ars.usda.gov

J. L. Hatfield

USDA-ARS, jerry.hatfield@ars.usda.gov

D. A. Laird

USDA-ARS, dalaird@iastate.edu

T. T. Hart

USDA-ARS

Y. S. Do

lowa State University

See next page for additional authors

Follow this and additional works at: https://digitalcommons.unl.edu/usdaarsfacpub

Zahn, J. A.; Hatfield, J. L.; Laird, D. A.; Hart, T. T.; Do, Y. S.; and DiSpirito, A. A., "Functional Classification of Swine Manure Management Systems Based on Effluent and Gas Emission Characteristics" (2001).

Publications from USDA-ARS / UNL Faculty. 1340.

https://digitalcommons.unl.edu/usdaarsfacpub/1340

This Article is brought to you for free and open access by the U.S. Department of Agriculture: Agricultural Research Service, Lincoln, Nebraska at DigitalCommons@University of Nebraska - Lincoln. It has been accepted for inclusion in Publications from USDA-ARS / UNL Faculty by an authorized administrator of DigitalCommons@University of Nebraska - Lincoln. 


\section{Authors}

J. A. Zahn, J. L. Hatfield, D. A. Laird, T. T. Hart, Y. S. Do, and A. A. DiSpirito

This article is available at DigitalCommons@University of Nebraska - Lincoln: https://digitalcommons.unl.edu/ usdaarsfacpub/1340 


\title{
Functional Classification of Swine Manure Management Systems Based on Effluent and Gas Emission Characteristics
}

\author{
J. A. Zahn,* J. L. Hatfield, D. A. Laird, T. T. Hart, Y. S. Do, and A. A. DiSpirito
}

\begin{abstract}
Gaseous emissions from swine (Sus scrofa) manure storage systems represent a concern to air quality due to the potential effects of hydrogen sulfide, ammonia, methane, and volatile organic compounds on environmental quality and human health. The lack of knowledge concerning functional aspects of swine manure management systems has been a major obstacle in the development and optimization of emission abatement technologies for these point sources. In this study, a classification system based on gas emission characteristics and effluent concentrations of total phosphorus (P) and total sulfur (S) was devised and tested on 29 swine manure management systems in Iowa, Oklahoma, and North Carolina in an effort to elucidate functional characteristics of these systems. Four swine manure management system classes were identified that differed in effluent concentrations of $\mathrm{P}$ and $\mathrm{S}$, methane $\left(\mathrm{CH}_{4}\right)$ emission rate, odor intensity, and air concentration of volatile organic compounds (VOCs). Odor intensity and the concentration of VOCs in air emitted from swine manure management systems were strongly correlated $\left(r^{2}=0.88\right)$. The concentration of VOC in air samples was highest with outdoor swine manure management systems that received a high input of volatile solids (Type 2). These systems were also shown to have the highest odor intensity levels. The emission rate for VOCs and the odor intensity associated with swine manure management systems were inversely correlated with $\mathrm{CH}_{4}$ and ammonia $\left(\mathrm{NH}_{3}\right)$ emission rates. The emission rates of $\mathrm{CH}_{4}, \mathrm{NH}_{3}$, and VOCs were found to be dependent upon manure loading rate and were indirectly influenced by animal numbers.
\end{abstract}

$\mathrm{I}^{\mathrm{n}}$ $\mathrm{N}$ the USA, approximately 157000 swine production

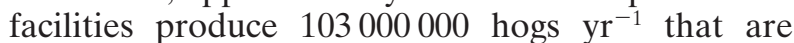
marketed in the USA and globally (American Society of Agricultural Engineers, 1988; Harkin, 1997). Annually, these production facilities produce more than $118520000 \mathrm{Mg} \mathrm{yr}^{-1}$ of manure that is often stored for periods up to 13 mo before land application (American Society of Agricultural Engineers, 1988; Harkin, 1997). Air quality studies have indicated that emissions released from stored swine manure have the potential to decay local, regional, and global air quality through the discharge of ammonia $\left(\mathrm{NH}_{3}\right)$ (Harper and Sharpe, 1997; Asman, 1995), nitrous oxide $\left(\mathrm{N}_{2} \mathrm{O}\right)$ (Sharpe and Harper, 1998), methane $\left(\mathrm{CH}_{4}\right)$ (Safley et al., 1992; Sharpe and Harper, 1997), hydrogen sulfide $\left(\mathrm{H}_{2} \mathrm{~S}\right)$ (Jacobson et al., 1997b), particulate matter (VanWicklen, 1997), and volatile organic compounds (VOCs) (Zahn et al., 1997). Much research has focused on the development of strat-

J.A. Zahn, National Swine Research Center, USDA-ARS, Ames, IA 50011. J.L. Hatfield, D.A. Laird, and T.T. Hart, National Soil Tilth Lab., USDA-ARS, Ames, IA 50011. Y.S. Do and A.A. DiSpirito, Dep. of Microbiology, Iowa State Univ., Ames, IA 50011. Disclaimer: Names are necessary to report factually on available data; however, the USDA neither guarantees nor warrants the standard of the product, and use of the name by USDA implies no approval of the product to the exclusion of others that may also be suitable. Received 16 Mar. 2000. *Corresponding author (zahn@nsric.ars.usda.gov).

Published in J. Environ. Qual. 30:635-647 (2001). egies to reduce or eliminate emissions and odors from stored animal manure. However, a major part of this research has not been applied by the swine industry due to economic restrictions or due to sporadic or ineffective performance of emission abatement approaches (Miner, 1982, 1995, 1999). Performance evaluations of emission abatement strategies often cite poorly understood microbiological processes or other poorly defined intrinsic properties of swine manure management systems as the reason for ineffective performance of a particular emission abatement method (Miner, 1995). However, the exact cause for many of these failures has remained speculative due to the lack of knowledge concerning functional aspects of animal manure management systems.

The purpose of this research was to develop a method to functionally classify swine manure management systems based on effluent chemical properties and emission rates of $\mathrm{CH}_{4}, \mathrm{NH}_{3}, \mathrm{H}_{2} \mathrm{~S}$, and VOC. A reliable method to functionally classify manure management systems would serve the agricultural industry as a management tool in evaluating best management practices for swine manure storage systems and would serve regulators as a rapid method to identify production sites that represent a potential air quality or nuisance concern.

\section{MATERIALS AND METHODS}

\section{Physical and Chemical Characterization of Stored Manure}

Effluent samples (200 mL each) and $\mathrm{pH}$ were taken at six locations at the center and around the perimeter of the manure management system at a minimum distance of $2.5 \mathrm{~m}$ from the edge of the storage impoundment and at a depth of $2 \mathrm{~cm}$ according to the method of DiSpirito et al. (1995). Measurements of $\mathrm{pH}$ were taken with a portable $\mathrm{pH}$-temperature meter (Model \#59002-00, Cole Parmer, Vernon Hills, IL). Total carbon $(\mathrm{C})$, nitrogen $(\mathrm{N})$, and hydrogen $(\mathrm{H})$ were determined on oven-dried $\left(100^{\circ} \mathrm{C}\right)$ effluent samples using a Model 2100 Perkin Elmer (Norwalk, CT) CHN analyzer. Percent values were converted to $\mathrm{g} \mathrm{L}^{-1}$ values based on solids content determined by gravimetric methods. Volatile solids concentration was determined by the difference in weight of oven-dried $\left(100^{\circ} \mathrm{C}\right)$ and ashed $\left(550^{\circ} \mathrm{C}\right)$ samples. Analysis of main-group elements and transition metal cations was performed on microwave-digested (Method SW 846-3015; CEM Corporation, 1996) effluent samples according to USEPA Method SW 8463015 (CEM Corporation, 1996). Quantitative analysis of digested samples was performed using a Thermo Jarrel Ash Model ICAP 61E inductively coupled plasma-atomic emission spectrometer (ICP-AES) and elemental concentration is reported as the mean \pm the standard error. Other physical and chemical parameters evaluated in this study included bacterial chlorophyll $a$ and $b$ concentration. Bacteriochlorophyll $a$ and

\footnotetext{
Abbreviations: VOC, volatile organic compound.
} 
$b$ was determined as previously described by Siefert et al. (1978) and DiSpirito et al. (1995). The bacteriochlorophyll $a$ concentration was calculated spectrophotometrically using a molar absorptivity coefficient of $e_{777}=75 \mathrm{~cm}^{-1} \mathrm{~m} M^{-1}$. Lagoons with bacteriochlorophyll $a$ concentrations above $40 \mathrm{nmol} \mathrm{mL}^{-1}$ are subsequently referred to as photosynthetic lagoons.

\section{Description of Swine Manure Storage Facilities, Placement of Air Monitoring Equipment, and Statistical Analyses}

Loading criteria and individual site descriptions for 29 swine manure management systems located in Iowa $(n=24)$, Oklahoma $(n=2)$, and North Carolina $(n=3)$, sampled during the months of August and September 1997, are described in Table 1. Individual manure management systems were separated into four main categories (Types 1-4) based on the concentration of total $\mathrm{P}$ and total $\mathrm{S}$ present in effluent samples. Average physical and chemical properties, as well as management attributes for these systems, are summarized in Table 1. Meteorological conditions (wind speed, relative humidity, irradiance, solution temperature at a $10-\mathrm{cm}$ depth, and air temperature) were monitored continuously and the sample mean was recorded in 0.5 -min intervals at the point of air sample collection by an integrated weather station (Sauer and Hatfield, 1994) that was positioned at the center of the outdoor manure storage systems. Height of the sensors was established by trajectory simulation models described in the micrometeorological flux methods section (theoretical profile shape) and was identical to the air sampling height used for micrometeorological flux measurements. Micrometeorological data was not collected for studies that employed dynamic flux chamber methods for determination of $\mathrm{CH}_{4}$ flux rates.

Statistical evaluation of data and experimental designs were performed with JMP Version 3 statistical discovery software (SAS Institute, 1998).

\section{Capture and Analysis of Air Pollutants from Swine Manure Management Systems}

Volatile organic compounds (VOCs) were captured on a multibed adsorbent tube containing a combination of Tenax TA and Carboxen-569 (Supelco, Bellefonte, PA), according to the low-volume sampling method developed by Zahn et al. (1997). For air sampling of VOC, flow rate through individual thermal desorption tubes was precisely regulated at $1.0 \mathrm{~L}$ $\min ^{-1}$ throughout the 30 -min sampling period, using thermal mass flow controllers (Series 810, Sierra Instruments, Monterey, CA) that were connected to a common, high-vacuum manifold. Desorption tubes were analyzed by gas chromatography using a flame ionization or mass selective detector as previously described by Zahn et al. (1997).

Ammonia $\left(\mathrm{NH}_{3}\right)$ was collected from air using two glass impingers (210 $\mathrm{mL}$ internal volume) arranged in series, each containing $25 \mathrm{~g}$ of 2-mm glass balls. Air samples were drawn by vacuum through a submerged fritted glass diffusion tube into $60 \mathrm{~mL}$ of $0.2 \mathrm{M}$ boric acid using a Buck (Orlando, FL) IH sampling pump operated at $1.0 \mathrm{~L} \mathrm{~min}^{-1}$. The boric acid solution was replaced in 30- to 120-min intervals depending on proximity of the sampler to the emission source. Ammonium concentration was determined by the salicylate-nitroprusside technique according to USEPA Method 351.2 (USEPA, 1979). Solutions of ammonium chloride in $0.2 M$ boric acid were used as reference standards to determine ammonium ion concentration. Hydrogen sulfide $\left(\mathrm{H}_{2} \mathrm{~S}\right)$ and $\mathrm{CH}_{4}$ were collected in 1.0-L Tedlar gas sampling bags (Supelco, Bellefonte, PA) and evaluated in the laboratory by previously described gas chromatographic methods using either a $0.32-\mathrm{mm} \times 30-\mathrm{m}$ SPB-1 sulfur fused silica column with flame photometric detection (Bulletin 876, Supelco, Bellefone, PA) or a $1 / 8$ in $\times 8 \mathrm{ft}$ HayeSep-Q packed column (Supelco) with thermal conductivity detection (Chan et al., 1998), respectively. Air samples for $\mathrm{H}_{2} \mathrm{~S}$ and $\mathrm{CH}_{4}$ analysis were drawn by vacuum into 1.0-L Tedlar gas sampling bags using a Model 1062 grab sampler (Supelco)

Table 1. Physical properties, elemental composition, and $\mathrm{CH}_{4}$ emission rates determined by flux chamber methods for 29 swine manure management systems located in Iowa, Oklahoma, and North Carolina during the months of August and September 1997. Values represent the mean \pm the standard error of the mean.

\begin{tabular}{|c|c|c|c|c|}
\hline \multirow[b]{2}{*}{ Parameter } & \multicolumn{4}{|c|}{ Site classification $\nleftarrow$} \\
\hline & Type $1 \ddagger$ & Type 2 & Type 3 & Type 4 \\
\hline Site number $(n)$ & $n=6$ & $n=7$ & $n=6$ & $n=10$ \\
\hline Manure management system description & $\begin{array}{l}\text { DP, } n=5 \\
\mathbf{P P}, n=1\end{array}$ & $\begin{array}{l}\text { EB, } n=3 \\
\text { CLB, } n=3 \\
\text { ST, } n=1\end{array}$ & $\mathbf{L}, n=6$ & PL, $n=10$ \\
\hline Methane emission rate $\left(\mathrm{g} \mathrm{CH}_{4}\right.$ system $^{-1} \mathrm{~h}^{-1}$ ) & $636 \pm 47$ & $1830 \pm 148$ & $13900 \pm 760$ & $11990 \pm 540$ \\
\hline Volatile solids loading rate $\left(\mathrm{kg}\right.$ VS $\left.\mathbf{d}^{-1} \mathrm{~m}^{-3}\right)$ & $79 \pm 3.0$ & $35 \pm 2.6$ & $\mathbf{0 . 3} \pm \mathbf{0 . 0 5}$ & $\mathbf{0 . 0 7} \pm \mathbf{0 . 0 2}$ \\
\hline pH & $7.1 \pm 0.04$ & $7.3 \pm 0.06$ & $7.3 \pm 0.06$ & $7.1 \pm \mathbf{0 . 0 3}$ \\
\hline Solid content $\left(\mathrm{mg} \mathrm{mL}^{-1}\right)$ & $21.9 \pm 0.9$ & $13.4 \pm 0.6$ & $3.8 \pm 0.4$ & $2.8 \pm 0.1$ \\
\hline$\%$ carbon ( \% dry mass) & $37.2 \pm 0.6$ & $33.7 \pm 0.5$ & $16.6 \pm 0.3$ & $14.1 \pm 0.3$ \\
\hline$\%$ hydrogen ( $\%$ dry mass) & $5.2 \pm \mathbf{0 . 3}$ & $4.9 \pm 0.2$ & $2.3 \pm 0.2$ & $1.8 \pm 0.1$ \\
\hline$\%$ nitrogen ( $\%$ dry mass) & $3.0 \pm 0.2$ & $2.9 \pm 0.2$ & $1.8 \pm 0.2$ & $1.5 \pm 0.1$ \\
\hline Ca $\left(m g \mathbf{L}^{-1}\right)$ & $301 \pm 38$ & $173 \pm 24$ & $\mathbf{5 8} \pm \mathbf{5}$ & $119 \pm 10$ \\
\hline $\mathrm{Cu}\left(\mathrm{mg} \mathrm{L} \mathbf{L}^{-1}\right)$ & $18 \pm 6.2$ & $1.7 \pm \mathbf{0 . 2}$ & $0.2 \pm 0.1$ & $0.2 \pm 0$ \\
\hline $\mathbf{F e}\left(\mathrm{mg} \mathrm{L}^{-1}\right)$ & $47 \pm 21.5$ & $8.9 \pm 1.2$ & $1.2 \pm 0.2$ & $0.7 \pm 0.4$ \\
\hline $\mathbf{K}\left(\mathrm{mg} \mathrm{L}^{-1}\right)$ & $1380 \pm 400$ & $1040 \pm 134$ & $624 \pm 18$ & $0.9 \pm 0.3$ \\
\hline $\mathrm{Mg}\left(\mathrm{mg} \mathrm{L}^{-1}\right)$ & $128 \pm 19$ & $62 \pm 10$ & $20 \pm 1.6$ & $39 \pm 4.0$ \\
\hline $\operatorname{Mn}\left(\mathrm{mg} \mathrm{L}^{-1}\right)$ & $3.2 \pm 0.8$ & $0.9 \pm 0.2$ & $0.1 \pm 0$ & $0.3 \pm 0.2$ \\
\hline $\mathrm{Na}\left(\mathrm{mg} \mathrm{L}^{-1}\right)^{\prime}$ & $241 \pm 86$ & $225 \pm 20.8$ & $165 \pm 4.6$ & $18 \pm 6.3$ \\
\hline $\mathbf{P}\left(\mathbf{m g ~ \mathbf { L } ^ { - 1 }}\right)$ & $504 \pm 26$ & $153 \pm 12.1$ & $65 \pm 4.5$ & $0.2 \pm 0$ \\
\hline $\mathbf{S}\left(\mathbf{m g} \mathbf{L}^{-1}\right)$ & $108 \pm 8$ & $39 \pm 5.3$ & $15 \pm 0.4$ & $\mathbf{8} \pm \mathbf{1 . 8}$ \\
\hline $\operatorname{Zn}\left(\operatorname{mg~L} L^{-1}\right)$ & $18.7 \pm 8$ & $2.7 \pm 0.4$ & $0.4 \pm 0.1$ & $\mathbf{0 . 1} \pm \mathbf{0}$ \\
\hline
\end{tabular}

$\dagger$ Values represent the mean for samples listed in Fig. 1. Instrumental error was $<1 \%$ for $\mathrm{CHN}$ analysis and $<0.1 \%$ for inductively coupled plasma-atomic emission spectrometry (ICP-AES) analysis.

+ Manure storage system designation as defined in Fig. 1. Type 1 systems represent confinement buildings with short- and long-term, under-slat storage (pull-plug and deep-pit systems). Type 2 systems represent earthen, concrete, or steel-lined manure storage basins. Type 3 and Type 4 systems represent lagoon systems without and with anoxic photosynthetic blooms, respectively. Subclassification designations: $\mathbf{P L}=$ phototrophic lagoon; $\mathbf{L}=$ lagoon; EB = earthen basin; CLB = concrete-lined basin (outdoor); ST = steel tank (outdoor); DP = deep pit; PP = pull-plug. 
operated at $25 \mathrm{~mL} \mathrm{~min}{ }^{-1}$. Teflon surfaces were equilibrated with analytes $\left(\mathrm{H}_{2} \mathrm{~S}\right.$ and $\left.\mathrm{CH}_{4}\right)$ present in the air sample by performing four fill-purge cycles before collection of the final air sample. Lead acetate strips (Model \#701, VICI Metronics, Santa Clara, CA) were used at the point of air sample collection (by Tedlar bag methods) to confirm gas chromatographic results for the quantification of $\mathrm{H}_{2} \mathrm{~S}$. The latter methods indicated that $\mathrm{H}_{2} \mathrm{~S}$ losses due to reaction or condensation were less than $4 \%$ if samples were analyzed within $6 \mathrm{~h}$ of collection. The concentration of $\mathrm{CH}_{4}$ in air was also determined in real time at two of the 29 swine manure management systems noted in Fig. 1 using a tunable-diode laser system operated in the infrared region at $2968.4034 \mathrm{~cm}^{-1}$, as previously described by Simpson et al. (1995). Concentration measurements of $\mathrm{CH}_{4}$ that were determined using the tunable-diode laser were converted to flux using the theoretical profile shape micrometeorological method. All other $\mathrm{CH}_{4}$ flux measurements performed in this study used $\mathrm{CH}_{4}$ concentration measurements that were determined by the gas chromatographic method. A combination of the air sampling methods described above was used to determine recovery efficiency and to validate the $\mathrm{H}_{2} \mathrm{~S}$ and $\mathrm{CH}_{4}$ sampling techniques.

\section{Evaluation of the Odor Intensity Associated with Swine Manure Management Systems}

Odor intensity was measured by the method of direct scaling in reference to an odor standard of defined intensity using three or four trained panelists (Cain et al., 1998; Degel and Koster, 1998; Liden et al., 1998; Livermore and Laing, 1998). Direct scaling was based on estimation of the intensity of olfactory sensations associated with an odor source by assigning numerical values to sensory stimuli. Sensory responses were normalized against the artificial swine odor reference standard Z2 (Zahn and DiSpirito, 2000) that consisted of 0.05 $\mathrm{m} M$ dimethyl disulfide, $8 \mathrm{~m} M$ acetic acid, $3.5 \mathrm{~m} M$ propionic acid, $0.5 \mathrm{~m} M$ isobutyric acid, $0.4 \mathrm{~m} M$ 2-butanol, $1.4 \mathrm{~m} M$ butyric acid, $0.2 \mathrm{~m} M$ isovaleric acid, $0.5 \mathrm{~m} M$ valeric acid, $0.1 \mathrm{~m} M$
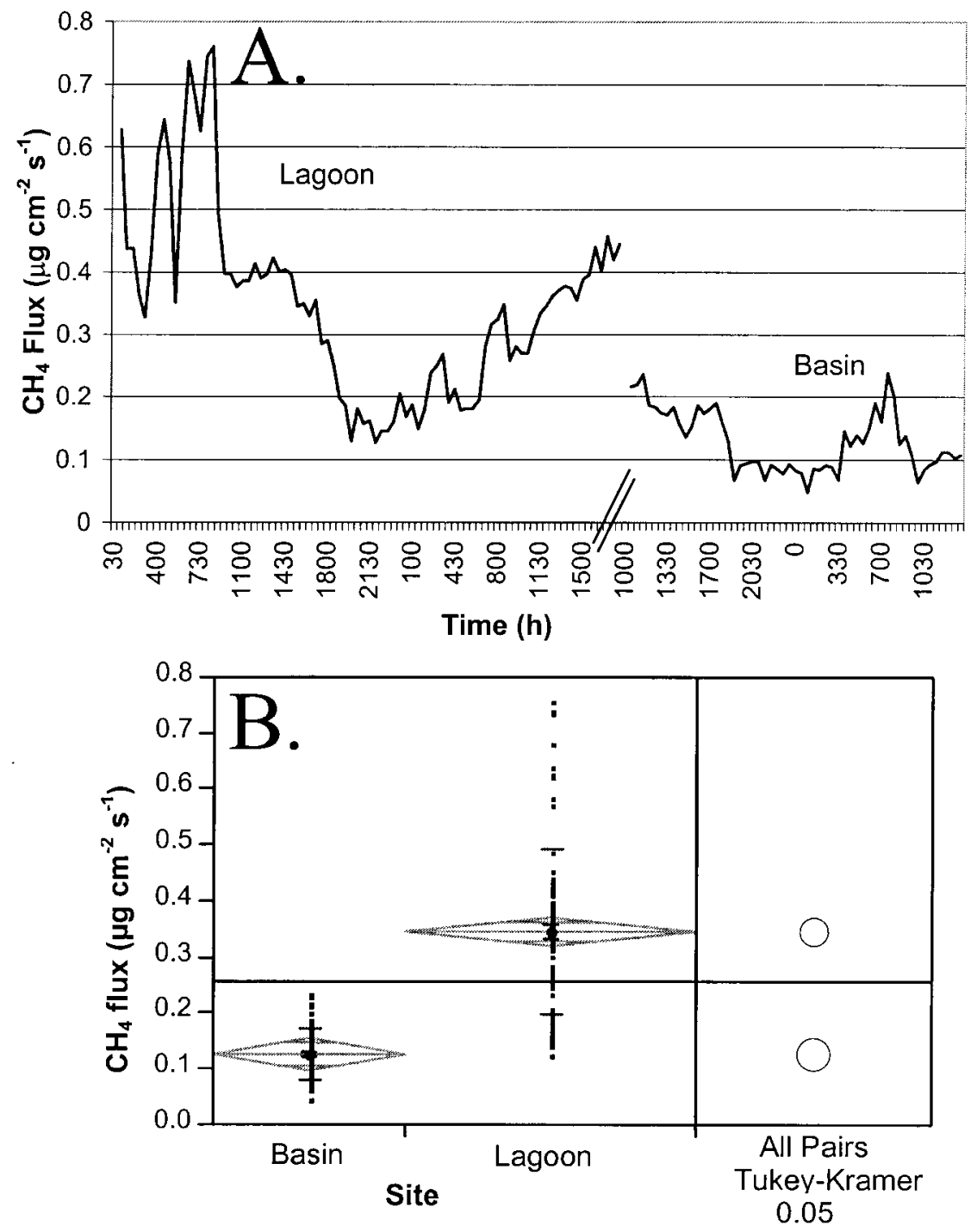

Fig. 1. Flux rate of $\mathrm{CH}_{4}$ from swine manure management systems differing in volatile solids loading rate as determined by the theoretical profile shape micrometeorological method and using the tunable diode laser method. $(A) \mathrm{CH}_{4}$ flux over a 30 -h period from a swine manure lagoon $\left(0.12 \mathrm{~kg}\right.$ volatile solids $\left.\mathrm{d}^{-1} \mathrm{~m}^{-3}\right)$ and over a 25 -h period for a swine manure basin $\left(37 \mathrm{~kg}\right.$ volatile solids $\left.\mathrm{d}^{-1} \mathrm{~m}^{-3}\right)$. The time period between $\mathrm{CH}_{4}$ measurements for sites was approximately $16 \mathrm{~h}$ and is indicated by the broken $x$ axis. $(B)$ One-way analysis of variance (ANOVA) ( $t$ test) for $\mathrm{CH}_{4}$ flux data and the Tukey-Kramer HSD means comparison table showing the absolute difference in the means minus the least significant difference (alpha level $=\mathbf{0 . 0 5})$. 
isocaproic acid, $0.2 \mathrm{~m} M$ caproic acid, $0.2 \mathrm{~m} M$ heptanoic acid, $0.1 \mathrm{~m} M$ indole, $0.15 \mathrm{~m} M$ 3-methyl indole, $0.2 \mathrm{~m} M$ 4-methyl phenol, $0.12 \mathrm{~m} M$ 4-ethyl phenol, $0.15 \mathrm{~m} M$ phenol, $0.1 \mathrm{~m} M$ benzyl alcohol, $0.15 \mathrm{~m} M$ 2-amino acetophenone, $0.1 \mathrm{~m} M$ butylated hydroxytoluene (added as a preservative), and $8 \mathrm{mM}$ ammonium acetate. Chemical composition of the artificial swine odor Z2 was optimized in a laboratory dynamic flux chamber to mimic emission parameters for VOCs emitted from a manure sample collected from a high-odor, Type 1 swine manure management system (Zahn et al., 2001). Pure compounds were dissolved in warm $\left(45^{\circ} \mathrm{C}\right)$ water while stirring and the solution $\mathrm{pH}$ was frequently adjusted to $\mathrm{pH} 7.0$ with $2 M$ potassium hydroxide. Approximately $15 \mathrm{~mL}$ of the solution was transferred to an amber serum vial $(30 \mathrm{~mL}$ nominal volume), capped with a silicone-Teflon septum, and then degassed under repeated cycles of vacuum and argon to create an anaerobic headspace. Samples were stored in the dark at ambient temperatures until they were used. Panelists were provided the synthetic swine odor solution $\mathrm{Z} 2$ in an uncapped $30 \mathrm{~mL}$-serum vial, a solution of $2 \mathrm{~m} M n$-butanol in a $30-\mathrm{mL}$ serum vial, and a site odor evaluation worksheet, previously described by Zahn (1997). Panelists then evaluated the $n$-butanol solution that was considered neutral (Grade 3/10), and the Z2 solution that was considered unpleasant (Grade $6.5 / 10)$ at a neutral distance $(>1000 \mathrm{~m})$ from the manure management system. Panelists were then positioned in the emission plume from the manure management system $(1.5 \mathrm{~m}$ from the emitting source at a height of $1.5 \mathrm{~m}$ ) and asked to compare the odor intensity with the reference standards. Numerical evaluations of the swine manure management systems ranged from neutral (3) to unbearable (10), and are reported as the sample mean. Air samples for VOC analysis were collected at the receptor $(1.5 \mathrm{~m}$ from the emitting source at a height of $1.5 \mathrm{~m}$ ) throughout the odor evaluation period.

\section{Measurement of Methane Flux, Volatile Organic Compound Concentration, and Odor Intensity from 29 Swine Manure Management Systems}

An initial screening study was completed at 29 swine manure management systems to measure the flux rate of $\mathrm{CH}_{4}$, odor intensity, concentration of VOCs in air at the point of the odor intensity measurements, and analytes in the effluent fraction. The flux rate of $\mathrm{CH}_{4}$, for this initial screening study, was measured at 29 manure management systems (lagoons, earthen basins, cement-lined basins, steel-lined tanks, and confinement pits) using a flux chamber described by DiSpirito and Zahn (1999). The dynamic flux chamber method was found to be most suitable for screening large sample numbers due to the minimum operation requirements, portability, and reliability for measurement of nonreactive gases such as $\mathrm{CH}_{4}$ (Chan et al., 1998). The dynamic flux chamber was positioned near the center of the swine manure management system, with the exception of deep and shallow pit systems, which were sampled at the pump-out positions near the wall of the pit. Chamber operational parameters were modified from semistatic to dynamic mode by installation of a sweep gas manifold. Compressed air (containing 1.1 parts per million by volume or $0.77 \mathrm{mg} \mathrm{m}^{-3} \mathrm{CH}_{4}$ ) sweep gas was provided to the enclosure at a flow rate of $2.0 \mathrm{~L} \mathrm{~min}^{-1}$ in a demand mode. Air pressure within the chamber was maintained at barometric pressure through the use of a silicone oil (impinger) purge valve, positioned on the gas supply manifold. The static pressure differential was maintained at $0 \pm 1.5 \mathrm{kPa}$ throughout the collection period with the use of a mercury manometer. Gases were removed from the chamber through $0.635-\mathrm{cm}$ i.d. Teflon tubing that was attached to a vacuum pump through an inline mass flow controller set at $2.0 \mathrm{~L} \mathrm{~min}^{-1}$, following a 1-h chamber equilibration period. Six individual air samples (about $750 \mathrm{~mL}$ each) were collected over a 3-h sampling period. Samples were analyzed for $\mathrm{CH}_{4}$ concentration by gas chromatography within $6 \mathrm{~h}$ of sample collection. The concentration of $\mathrm{CH}_{4}$ in air samples was converted to trace gas flux density $(f)$ through the equation:

$$
f=(s / a)\left(C_{\mathrm{o}}-C_{\mathrm{i}}\right)
$$

where $s=$ sweep flow rate $\left(2.025 \mathrm{~L} \mathrm{~min}^{-1}\right), a=$ chamber basal area $\left(2500 \mathrm{~cm}^{2}\right), C_{0}=$ concentration of methane in the exit air $\left(\mathrm{mg} \mathrm{m}^{-3}\right)$, and $C_{\mathrm{i}}=$ concentration of $\mathrm{CH}_{4}$ in the sweep gas $\left(0.77 \mathrm{mg} \mathrm{m}^{-3}\right)$. In addition to the collection of samples for $\mathrm{CH}_{4}$ flux measurements, odor intensity and VOC concentration in air were taken at the receptor $(1.5 \mathrm{~m}$ from the emitting source at a height of $1.5 \mathrm{~m}$ ). Samples were collected at $1.0 \mathrm{~L} \mathrm{~min}^{-1}$ during the 30 -min olfactory evaluation period.

\section{Detailed Studies of Gas Flux Rates from Four Swine Manure Management Systems}

The flux rate of $\mathrm{CH}_{4}, \mathrm{H}_{2} \mathrm{~S}, \mathrm{NH}_{3}$, and VOCs was measured continuously at four swine manure management systems throughout a $24-\mathrm{h}$ period using the theoretical profile shape micrometeorological flux measurement method. The four sites chosen for this comprehensive study represented each of the four classes of swine manure management systems defined in Table 1. The theoretical profile shape method was chosen instead of chamber methods, since the latter methods adversely affected VOC emission profiles. Higher flux rates of disulfide compounds (dimethyl disulfide and dimethyl trisulfide) and lower flux rates of sulfide compounds (methyl mercaptan) were consistently observed with flux chamber methods when compared with micrometeorological methods. This observation indicated that the chamber surfaces were potentially the site of oxidation reactions for reactive gases $\left(\mathrm{H}_{2} \mathrm{~S}, \mathrm{NH}_{3}\right.$, and VOCs). These results are consistent with previous studies that show significant reduction in the concentration of VOCs collected from air if samples were drawn through glass or polymeric tubing (Zahn et al., 1997).

The flux of $\mathrm{NH}_{3}, \mathrm{H}_{2} \mathrm{~S}, \mathrm{CH}_{4}$, and VOCs from the lagoon was measured using the theoretical profile shape method described by Wilson et al. (1982). The emission rate of gases from a circular source plot was calculated with the following equation:

$$
\bar{F}_{\mathrm{z}}(0)=\frac{(u c)^{\text {measured }}}{\Phi}
$$

where $F_{z}(0)$ is the vertical flux rate in $\mu \mathrm{g} \mathrm{cm}^{-2} \mathrm{~s}^{-1}, \Phi$ is the nondimensional normalized horizontal flux predicted by the trajectory simulation model, and $(u c)^{\text {measured }}$ is the product of the measured average wind velocity and air concentration of analyte in $\mathrm{m} \mathrm{s}^{-1}$ and $\mu \mathrm{g} \mathrm{m}^{-3}$, respectively (Majewski et al., 1989; Majewski, 1990). Flux measurements were completed at the center of swine waste management systems with a circular shape. System classification based on the concentration ratio of phosphorus to sulfur (Table 1) and the requirement for circular manure management systems served as the major criteria for selecting the four swine waste management systems that were sampled for follow-up studies.

The surface roughness was determined before the sampling period began by performing mean wind velocity profile measurements at $0.2,0.5,1.0,2.0$, and $3.0 \mathrm{~m}$ for a period of $1 \mathrm{~h}$ at the center of the swine manure management system with cup anemometers (Model 03101-5, R.M. Young Co., Traverse City, MI). The mean value for roughness length at the surface of outdoor swine manure management systems, during periods 
of neutral atmospheric stability (mid-morning), was $0.10 \pm$ $0.02 \mathrm{~cm}$ (mean \pm standard error). The following measurement parameters were used to establish the sampling height: Type $1=$ total mechanically ventilated exhaust flow rate $=110000$ $\mathrm{m}^{3} \mathrm{~h}^{-1}$, sampling position at the fan orifices (four total); Type $2=39$-m-diam. basin, $z=$ ZINST $(0.1 \mathrm{~cm}$ roughness length, $1950 \mathrm{~cm}$ radius $=70 \mathrm{~cm}$ sampling height); Type $3=92-\mathrm{m}-$ diam. lagoon, $z=$ ZINST $(0.1 \mathrm{~cm}$ roughness length, $4600 \mathrm{~cm}$ radius $=189 \mathrm{~cm}$ sampling height $)$; Type $4=$ a primary $100-\mathrm{m}-$ diam. photosynthetic lagoon, $z=$ ZINST $(0.1 \mathrm{~cm}$ roughness length, $5000 \mathrm{~cm}$ radius $=191 \mathrm{~cm}$ sampling height). Error in measurement height that was associated with temporal changes in roughness length for the lagoon surface was estimated to cause a maximum error of $8 \%$ in the height parameter for emission measurements.

Flux measurements using the theoretical profile shape method were based on the concentration of airborne analytes present at a measurement height $(z)$ and meteorological data, collected at the same point (Majewski, 1990). Measurement height $(z)$ was calculated by trajectory simulation models and was based on system surface area and roughness length (Wilson et al., 1982). In addition to the air samples that were collected over the emitting source, two to five air samples were collected at the beginning of each sampling period, upwind from each manure storage system, to assess background air concentrations of target analytes and to confirm the source of these emissions. Background analyte concentrations were assumed to remain constant throughout the sampling period and were subtracted from analyte concentrations that were observed above each emitting source. Background concentrations for analytes at each of the four sites sampled in followup studies were as follows. Type 1: 6.0 parts per billion by volume (ppbv) $\left(8.5 \mu \mathrm{g} \mathrm{m}^{-3}\right) \mathrm{H}_{2} \mathrm{~S}, 15.0 \mathrm{ppbv}\left(11.1 \mu \mathrm{g} \mathrm{m}^{-3}\right)$ $\mathrm{NH}_{3}$, and 1.3 parts per million by volume (ppmv) $(0.91 \mathrm{mg}$ $\left.\mathrm{m}^{-3}\right) \mathrm{CH}_{4}$. Type 2: 15 ppbv $\left(21.3 \mu \mathrm{g} \mathrm{m}^{-3}\right) \mathrm{H}_{2} \mathrm{~S}, 11.0$ ppbv $(8.1$ $\left.\mu \mathrm{g} \mathrm{m}^{-3}\right) \mathrm{NH}_{3}$, and $1.3 \mathrm{ppmv}\left(0.91 \mathrm{mg} \mathrm{m}^{-3}\right) \mathrm{CH}_{4}$. Type 3: 12 ppbv $\left(17.1 \mu \mathrm{g} \mathrm{m}^{-3}\right) \mathrm{H}_{2} \mathrm{~S}, 7.0$ ppbv $\left(5.2 \mu \mathrm{g} \mathrm{m}^{-3}\right) \mathrm{NH}_{3}$, and 1.2 ppmv $\left(0.84 \mathrm{mg} \mathrm{m}^{-3}\right) \mathrm{CH}_{4}$. Type 4: $9.0 \mathrm{ppbv}\left(12.8 \mu \mathrm{g} \mathrm{m}^{-3}\right) \mathrm{H}_{2} \mathrm{~S}$, $8.0 \mathrm{ppbv}\left(5.9 \mu \mathrm{g} \mathrm{m}^{-3}\right) \mathrm{NH}_{3}$, and $1.3 \mathrm{ppmv}\left(0.91 \mathrm{mg} \mathrm{m}^{-3}\right) \mathrm{CH}_{4}$. The concentration of VOCs in background air samples was below the detection limit of $0.2 \mathrm{ppb}$ for all samples that were analyzed.

Flux rate measurements for the mechanically ventilated deep-pit swine manure management system (animal confinements) were performed by continuously monitoring exhaust flow rate during the sample collection period at two pit fan and two ventilation fan orifices using a three-dimensional sonic anemometer (Campbell Scientific, Logan, UT). Air samples were collected near the lower sensor arm on the anemometer in the exhaust stream.

\section{RESULTS AND DISCUSSION}

\section{Initial Evidence that Methane Emission Rate is Dependent upon Manure Management System Environment}

Studies were conducted on two types of manure management systems located on a feeder-to-finish swine production facility in central Iowa in August 1997 to assess differences in $\mathrm{CH}_{4}$ emission rate that could be attributed to differences in manure management system environment. Swine waste material entering the manure management system environments originated from animals of the same breeding population that were fed identical diets, were of similar weight, and were managed under similar management routines (feeding schedules and rates). Volatile solids loading rate, however, differed between the two systems by more than 300 -fold ( 37 vs. $0.12 \mathrm{~kg}$ volatile solids $\mathrm{d}^{-1} \mathrm{~m}^{-3}$ ). For the basin system $\left(37 \mathrm{~kg}\right.$ volatile solids $\left.\mathrm{d}^{-1} \mathrm{~m}^{-3}\right)$, manure was emptied daily from the confinement into an outdoor concrete holding tank and for the lagoon system $(0.12 \mathrm{~kg}$ volatile solids $\mathrm{d}^{-1} \mathrm{~m}^{-3}$ ), manure was flushed into the earthen holding basin by an intermittent loop flush system. Methane flux measurements were performed on three separate occasions in August 1997 with a tunablediode laser over the center of the manure management systems using the theoretical profile shape method for measuring evaporative fluxes (Fig. 1). While similar $\mathrm{CH}_{4}$ flux values were observed for systems over the three separate sampling periods, only a single comparison is reported, since this sampling period demonstrated the greatest similarity between sites for environmental conditions known to influence $\mathrm{CH}_{4}$ flux. Measured environmental conditions over the 68 -h sampling period included wind speed $\left(2.2 \pm 0.14\right.$ vs. $2.4 \pm 0.12 \mathrm{~m} \mathrm{~s}^{-1}$ [mean and standard error mean]), irradiance (298 \pm 35 vs. $\left.305 \pm 30 \mathrm{~W} \mathrm{~cm}^{-2}\right)$, relative humidity $(\mathrm{RH})(85 \pm 2 \mathrm{vs}$. $78 \pm 2 \% \mathrm{RH})$, air temperature $(18.6 \pm 0.4$ vs. $22.6 \pm$ $\left.0.5^{\circ} \mathrm{C}\right)$, and solution temperature at a $10-\mathrm{cm}$ depth $(27 \pm$ 0.2 vs. $23 \pm 0.3^{\circ} \mathrm{C}$ ) for the lagoon and basin, respectively. Results from $\mathrm{CH}_{4}$ micrometeorological flux measurements indicated that there were statistically significant differences in both the flux rate $(0.35 \pm 0.02$ vs. $0.13 \pm$ $0.01 \mu \mathrm{g} \mathrm{CH} \mathrm{Cm}_{4}^{-2} \mathrm{~s}^{-1}$ [mean and standard error mean]) and emission rate ( 14.7 vs. $0.5 \mathrm{~g} \mathrm{CH}_{4}$ system $\left.^{-1} \mathrm{~s}^{-1}\right)$ for the lagoon and basin, respectively (Fig. 1). Current literature values for $\mathrm{CH}_{4}$ emissions from stored swine manure have been reported over a range of nearly two orders of magnitude (Harper and Sharpe, 1997). Harper and Sharpe (1997) proposed that the discrepancies between emission values might be explained by differences in measurement methods or due to atypical flux event periods. In addition to these explanations, results described in these experiments indicate that manure management environment, and specifically loading rate, may significantly influence the flux rate of $\mathrm{CH}_{4}$. While these observations are not novel in the context of laboratory anaerobic digestion processes (Oleszkiewicz and Sharma, 1990; Hill and Bolte, 1989), they do represent the first report of such a phenomena occurring under production scale conditions in an animal manure management system. The proceeding experiments were focused on defining relationships between effluent chemical properties of various swine manure management systems and observed emission characteristics in order to further define the relationship between system loading rate and emission rate of $\mathrm{CH}_{4}, \mathrm{NH}_{3}, \mathrm{H}_{2} \mathrm{~S}$, and VOCs.

\section{Classification of 29 Swine Manure Management Systems Based on Solution-Phase Chemistry and Methane Emission Rate}

The concentration range for elements found in the swine manure storage systems sampled in this study were found to be similar to those previously reported 
by Giusquiani et al. (1998), Japenga and Harmsen (1990), and Zahn et al. (1997) (Table 1). There was a weak positive correlation observed between volatile solids loading rate and concentration of elements for each of the samples evaluated (Table 1). Individual correlations between element concentration and volatile solids loading rate indicated that volatile solids loading rate could account for 48 to $76 \%$ of the variability observed with effluent concentration of elements. This inadequacy of volatile solids loading rate to account for differences in effluent elemental composition for various swine manure management systems, in addition to the low-throughput of volatile solids measurements, indicated that the solution concentration of elements may provide a more appropriate means to classify swine manure management systems.

In the search for useful effluent chemical classification criteria, 45 pairwise comparisons were made between the concentrations of elements present in the 29 site samples. The nonparametric measure of association for each pairwise comparison is shown in Table 2. In general, a lower level of correlation was observed for pairwise comparisons made between elements showing opposite partitioning behavior (Table 2). For example, transition metal ions have been shown to partition strongly into the sludge or particulate fraction of the manure, while sodium $(\mathrm{Na})$, potassium $(\mathrm{K})$, and to a lesser extent, phosphorus $(\mathrm{P})$, magnesium $(\mathrm{Mg})$, and sulfur (S), demonstrate neutral or preferential partitioning behavior into the supernatant fraction of the manure (Giusquiani et al., 1998; Zahn et al., 1997). Therefore, the concentration of transition metal ions in samples is highly dependent upon the concentration of suspended solids, while $\mathrm{Na}$ and $\mathrm{K}$ are nearly independent of the concentration of suspended solids. High correlation coefficients were observed for pairwise comparisons between several transition metals, for several transition metals and a small number of main group elements, and finally, for $\mathrm{P}$ and $\mathrm{S}$ concentrations in the 29 site samples. However, only one pairwise comparison (P and S) demonstrated clear functional clustering of manure management systems based on system $\mathrm{CH}_{4}$ emission rate, air concentration of VOCs, or odor intensity (Fig. 2, Table 2).

The 29 swine manure management systems were observed to cluster into four distinct system subtypes (Types 1-4) based on the concentration of S and P in the effluent fraction (Fig. 2, Table 1). No statistical differences were observed for $\mathrm{CH}_{4}$ emission rates between Type 1 and 2 systems, nor between Type 3 and 4 systems. However, $\mathrm{CH}_{4}$ emission rates for all other comparisons were statistically different (Fig. 2B). The mean odor intensity values for sampling sites showed a clustering behavior that was similar to the clustering of data points based on effluent $\mathrm{P}$ and $\mathrm{S}$ concentrations or system $\mathrm{CH}_{4}$ emission rate. However, odor intensity showed nearly an inverse relationship to $\mathrm{CH}_{4}$ emission rate, with the highest odor intensities occurring with manure management systems having the lowest $\mathrm{CH}_{4}$ emission rates (Type 1 and 2 systems).

Odor intensities and VOC concentrations in Type 2 systems were consistently higher than measurements performed on Type 1 systems. This result was not entirely consistent with effluent $\mathrm{P}$ and $\mathrm{S}$ concentrations or with system $\mathrm{CH}_{4}$ emission rates, which predicted Type 1 systems to have the highest odor intensities and air concentrations of VOCs. Gas transfer coefficients for $\mathrm{CH}_{4}$ and VOCs are known to differ by several hundredfold (MacIntyre et al., 1995). In addition to large differences in gas transfer coefficients for $\mathrm{CH}_{4}$ and VOCs, surface exchange rate for some VOCs is known to be influenced by effluent chemical events that include ionization $(\mathrm{pH})$, hydrogen bonding, and surface slicks (MacIntyre et al., 1995). For these reasons, $\mathrm{CH}_{4}$ emission rate is not an appropriate criterion for predicting VOC volatilization potential between swine manure management systems. Wind, temperature, and irradiance are known to be major factors in the emission rate of sparingly soluble gases (VOCs) from liquid or semisolid surfaces (MacIntyre et al., 1995; Zahn et al., 1997). Based on the VOC transfer coefficient calculations from MacIntyre et al. (1995), the difference due to wind and temperature exposures between outdoor and indoor manure management systems can account for between 51 and $93 \%$ of the observed differences in VOC emissions. This analysis provides evidence that exposure factors can account for differences observed in VOC flux rates, VOC air concentrations, and odor intensity between Type 1 and 2 systems.

Swine manure management systems are often designed to release gases produced in anaerobic decomposition processes into the atmosphere. Within these systems, a complex consortium of microorganisms (anaerobic food chain) decompose complex biological

Table 2. Results for the pairwise comparison of element concentrations present in effluent samples from 29 swine manure management systems. Values indicate the nonparametric measure of association between pairwise comparisons of elements.

\begin{tabular}{|c|c|c|c|c|c|c|c|c|c|c|}
\hline \multirow[b]{2}{*}{ Element } & \multicolumn{10}{|c|}{ Nonparametric measure of association (Spearmans rho value) } \\
\hline & Ca & $\mathrm{Cu}$ & $\mathbf{F e}$ & $\mathbf{K}$ & Mg & Mn & $\mathbf{N a}$ & $\mathbf{P}$ & $\mathbf{S}$ & $\mathbf{Z n}$ \\
\hline Ca & 1 & 0.65 & 0.80 & 0.92 & 0.82 & 0.37 & 0.66 & 0.66 & 0.66 & 0.66 \\
\hline $\mathbf{C u}$ & & 1 & 0.92 & 0.70 & 0.66 & 0.83 & 0.65 & 0.96 & 0.92 & 0.96 \\
\hline $\mathbf{F e}$ & & & 1 & 0.64 & 0.78 & 0.95 & 0.59 & 0.93 & 0.89 & 0.91 \\
\hline $\mathbf{K}$ & & & & 1 & 0.36 & 0.56 & 0.96 & 0.74 & 0.74 & 0.67 \\
\hline $\mathbf{M g}$ & & & & & 1 & 0.83 & 0.30 & 0.69 & 0.68 & 0.66 \\
\hline Mn & & & & & & 1 & 0.50 & 0.87 & 0.85 & 0.84 \\
\hline $\mathbf{N a}$ & & & & & & & 1 & 0.67 & 0.66 & 0.62 \\
\hline $\mathbf{P}$ & & & & & & & & 1 & 0.94 & 0.96 \\
\hline $\mathbf{S}$ & & & & & & & & & 1 & 0.93 \\
\hline $\mathbf{Z n}$ & & & & & & & & & & 1 \\
\hline
\end{tabular}


waste material to end-products including $\mathrm{CH}_{4}, \mathrm{H}_{2} \mathrm{~S}, \mathrm{CO}_{2}$, and $\mathrm{NH}_{3}$ (Gottschalk, 1988; Lana et al., 1998; Mackie et al., 1998; Fenchel and Finlay, 1994). The anaerobic food chain is often functionally separated into microorganisms catalyzing acid-producing reactions from complex organic substrates and Archaea, which catalyze $\mathrm{CH}_{4}$-producing reactions from products formed in the breakdown of complex organic substrates (Deppenmeier et al., 1996; Fenchel and Finlay, 1994). The emission rate of $\mathrm{CH}_{4}$ and partially decomposed microbial substrates (volatile fatty acids) has been previously employed as an indicator to assess functional coupling between processes in the anaerobic food chain in anaerobic digesters (Hill and Bolte, 1989). Overloaded anaerobic digestion processes have been correlated with high emission rates of VOCs and low emission rates of $\mathrm{CH}_{4}$, while optimum loading rates promote high bioconversion efficiencies of complex organic matter into $\mathrm{CH}_{4}$ (Hill and Bolte, 1989). Data in Fig. 2 and Table 1 provide evidence that the biological processing events occurring in high-load systems (Type 1 and Type 2) may result from the functional decoupling of the anaerobic food chain. This observation is further supported by the fact that these same systems show an accumulation of organic (particulate $\mathrm{C}, \mathrm{H}, \mathrm{N}$ ) material (Table 1) and high air concentrations of VOCs (Fig. 3; Table 3). In contrast, the high emission rates for $\mathrm{CH}_{4}$ and low liquid-phase organic content (particulate $\mathrm{C}, \mathrm{H}, \mathrm{N}$ ) associated with Type 3 and 4 systems (Table 1 ) indicate that the environment in these systems provides for relatively more efficient bioconversion of complex organic substrates into $\mathrm{CH}_{4}$.

Data reported in this study were collected in three geographical regions of the USA over a 6-wk period in the late summer (August and September, 1997). This experimental design was chosen based on previous reports that bacterial photosynthetic and $\mathrm{SO}_{4}$ reduction activities in swine manure management systems located in northern U.S. climates reach a near steady-state condition during this time period (Do et al., 1998, 1999; Jacobson et al., 1997a). A second objective of this design was to identify differences in emission or effluent properties of swine manure management systems that could be attributed to geographical location (Iowa, $n=24$; Oklahoma, $n=2$; and North Carolina, $n=3$ ). However, no significant differences were observed in any of the parameters measured in this study when like manure management systems (i.e., photosynthetic lagoons vs. photosynthetic lagoons) were compared on the basis of geographic location. While the certainty of this finding is diminished by the low sample number, it was not entirely surprising that effects of geographic location played a minor role in the emission characteristics of (steady-state) manure management systems when contrasted to the effects due to loading rate. While the effects of geographic location on emission parameters appeared to be insignificant, geographic location was found to influence the rate at which the apparent steadystate condition was achieved. Based on the population dynamics of purple nonsulfur photosynthetic popula- tions, it has been noted that that the apparent steadystate condition occurs at least 1.2 mo earlier in North Carolina lagoons when compared to functionally similar lagoon systems in Iowa (Do et al., 1998). The seasonal
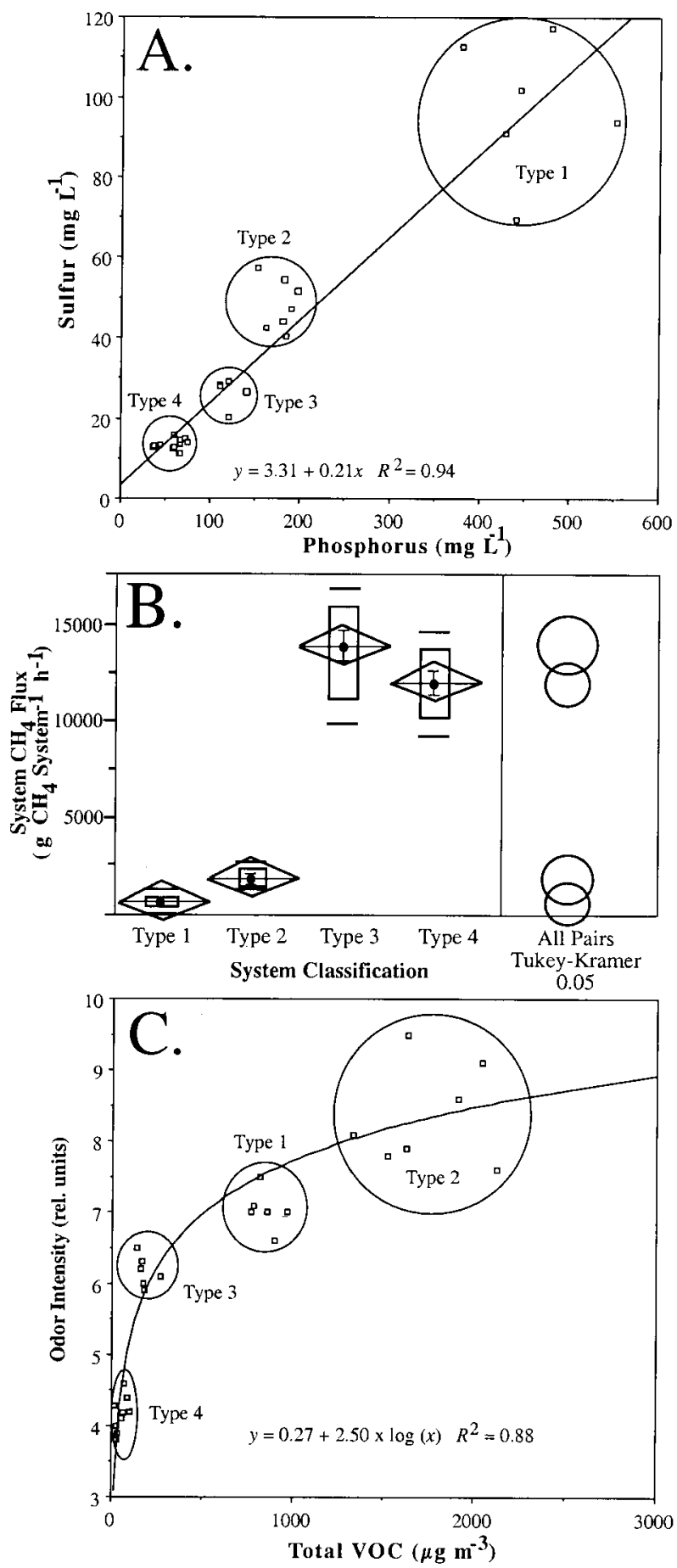

Fig. 2. Cluster analysis for $(A)$ concentration of total phosphorous versus total sulfur in effluent from 29 swine manure management systems. (B) Analysis of variance (ANOVA) (compare all pairs) for $\mathrm{CH}_{4}$ emission rate from swine manure management systems categorized according to phosphorus and sulfur concentrations and the Tukey-Kramer HSD means comparison table (alpha level $=$ 0.05). (C) Correlation between the concentration of VOCs present in air from manure management systems versus the mean odor intensity. 


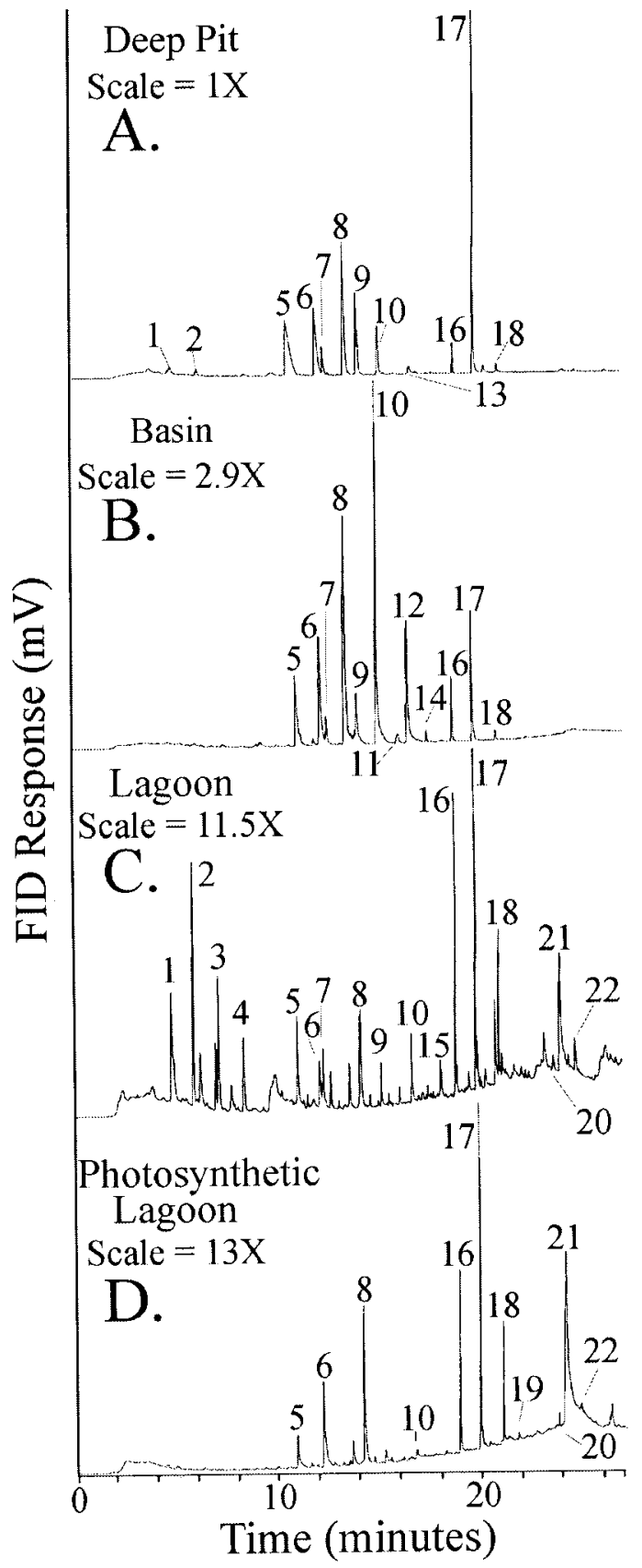

Fig. 3. Gas chromatograms of volatile organic emissions from swine manure storage systems representing the four system subtypes. From top to bottom: air sample collected in a deep pit (Type 1), air sample collected over a concrete-lined basin (Type 2), air sample collected over a lagoon (Type 3), and air sample collected over a photosynthetic lagoon (Type 4). Peak reference numbers correspond to organic compounds listed in Table 3.

transition in $\mathrm{P}$ and $\mathrm{S}$ concentrations for photosynthetic lagoons in Iowa progresses from "basin-like" characteristics in early spring $\left(100 \mathrm{mg} \mathrm{L}^{-1} \mathrm{P}\right.$ and $30 \mathrm{mg} \mathrm{L}^{-1} \mathrm{~S}$ ) to intermediate concentrations ("lagoon-like") in late spring ( $60 \mathrm{mg} \mathrm{L}^{-1} \mathrm{P}$ and $16 \mathrm{mg} \mathrm{L}^{-1} \mathrm{~S}$ ), to low concentrations during the photosynthetic bloom event in late June (1 $\mathrm{mg} \mathrm{L}^{-1} \mathrm{P}$ and $8 \mathrm{mg} \mathrm{L}^{-1} \mathrm{~S}$ ) (Do et al., 1998). Maximum methane flux during these transition events was observed to occur shortly (2-9 d) before the photosynthetic bloom (Do et al., 1998). These studies indicate that the $\mathrm{P}$ and $\mathrm{S}$ concentrations may provide valuable swine manure management classification information regardless of the season or geographical location.

\section{Relationships between Emission Chemistry and Odor Intensity}

Several recent investigations have attempted to define relationships between chemical concentration of specific gases and odor concentration or intensity (Hobbs et al., 1995; Jacobson et al., 1997a,b; ObrockHegel, 1997; Pain et al., 1990). Obrock-Hegel (1997) found that nutritional manipulation of amino acid intake reduced $\mathrm{NH}_{3}$, cresols, and indoles measured in air samples from production environments. However, no reduction in odor concentration was observed between control and treatment samples. Schulte et al. (1985) and Hobbs et al. (1995) linked high levels of ammonia $\left(\mathrm{NH}_{3}\right)$ to odor. Unfortunately, the latter authors noted that the relationship between $\mathrm{NH}_{3}$ and odor could not be universally applied to all farms, especially when they differed in the type of manure management system used. The use of hydrogen sulfide $\left(\mathrm{H}_{2} \mathrm{~S}\right)$ as a surrogate of livestock manure odor has also proven to be a formidable challenge. Jacobson et al. (1997b) evaluated odor and $\mathrm{H}_{2} \mathrm{~S}$ concentration in air from approximately 60 different pig, dairy, beef, and poultry manure storage units on farms in Minnesota. Low correlation was observed between $\mathrm{H}_{2} \mathrm{~S}$ and odor concentration for manure storages based on a species comparison and for production systems grouped according to manure management system type (pit, basin, and lagoon). The study further suggested the possibility that chemical odorants other than $\mathrm{H}_{2} \mathrm{~S}$ (i.e., VOCs) were responsible for swine odor. In support of this conclusion, Powers et al. (1999) recently demonstrated that effluent concentrations of several VOCs present in anaerobic digester effluent were correlated with odor intensity. However, effluent concentration of VOC did not predict odor intensities well enough to suggest that human panels should be eliminated. Data quality in the latter study was probably negatively influenced by the fact that correlations were not performed in a similar matrix (air vs. liquid). Previous studies have established that effluent measurements often provide an inaccurate representation of malodor potential and therefore represent an inappropriate comparison (Zahn et al., 1997).

To test the potential relationship between airborne VOCs and swine manure odor, odor intensity and air concentration of VOCs were determined simultaneously at the 29 swine production facilities. Figure $2 \mathrm{C}$ shows the relationship between average odor intensity, assessed through direct scaling techniques using a defined odor intensity, and the total air concentration of VOCs present at the receptor. The relationship between mean odor intensity and air concentration of VOCs was observed to obey Michaelis-Menten kinetics, with a Michaelis constant $\left(K_{\mathrm{m}}\right)$ of $95 \mu \mathrm{g} \mathrm{m}^{-3}$ VOCs and receptor saturation occurring at $1250 \mu \mathrm{g} \mathrm{m}^{-3}$ VOCs (Fig. 2). The saturation properties showed typical second-order 
Table 3. The mean concentration of trace gases and volatile organic compounds (VOCs) present in air samples from four swine manure management systems representing each system class. Values reported represent the sample mean for a 24-h sampling period and the standard error was less than $3 \%$ of the mean. Sample number site ${ }^{-1}$ : VOC, $n=12 ; \mathrm{NH}_{3}, \mathrm{CH}_{4}$, and $\mathrm{H}_{2} \mathrm{~S}, n=24$.

\begin{tabular}{|c|c|c|c|c|c|}
\hline \multirow{2}{*}{$\begin{array}{l}\text { Peak \# and } \\
\text { retention } \\
\text { time (min) }\end{array}$} & \multirow[b]{2}{*}{ Compound } & \multicolumn{4}{|c|}{ Swine manure management system type } \\
\hline & & Type $1 \dagger$ & Type 2 & Type 3 & Type 4 \\
\hline & & \multicolumn{4}{|c|}{$\begin{array}{l}\text { analyte air concentration }\left(\mu \mathrm{g} \mathrm{m}^{-3}\right) \text { and } \\
\text { percent total peak area }(\%)\end{array}$} \\
\hline Spec & ammonia & 9623 & 7923 & 9362 & 10843 \\
\hline GC-FID & methane & 5002 & 8406 & 18703 & 24406 \\
\hline GC-FPD & hydrogen sulfide $\nleftarrow$ & 54 & 48 & 27 & 29 \\
\hline $1(4.8)$ & dimethyl disulfide & $12(1.3)$ & nd & 17 (6.8) & nd \\
\hline 2 (6.1) & 2-butanol & $8(0.8)$ & nd & 19 (7.5) & nd \\
\hline $3(7.5)$ & dimethyl trisulfide & nd & nd & 13 (5.2) & nd \\
\hline 4 (8.6) & unknown & nd & nd & $-(2.9)$ & nd \\
\hline 5 (10.6) & acetic acid & $281(15.2)$ & 262 (7.6) & $11(2.7)$ & $2(2.3)$ \\
\hline 6 (11.9) & propionic acid & 126 (11.1) & $50(2.3)$ & $5(1.9)$ & $4(8.2)$ \\
\hline 7 (12.4) & isobutyric acid & $23(2.5)$ & 107 (11.4) & $6(2.2)$ & nd \\
\hline 8 (13.3) & butyric acid & 142 (15) & $586(32)$ & $13(5.1)$ & $5(12.9)$ \\
\hline $9(14.0)$ & isovaleric acid & 73 (8.3) & $98(6)$ & $3(1.2)$ & nd \\
\hline $10(15.0)$ & n-valeric acid & $43(4.9)$ & 360 (27) & $5(2.0)$ & $1(0.7)$ \\
\hline 11 (15.7) & isocaproic acid & nd & $10(0.5)$ & nd & nd \\
\hline 12 (16.0) & n-caproic acid & nd & $105(7.4)$ & nd & nd \\
\hline 13 (16.1) & unknown & $-(1.2)$ & nd & nd & nd \\
\hline 14 (16.6) & heptanoic acid & nd & $8(0.3)$ & nd & nd \\
\hline 15 (17.2) & benzyl alcohol & nd & nd & 2 (1.2) & nd \\
\hline 16 (18.8) & phenol & 9 (1.5) & 24 (1.6) & $8(6.9)$ & $3(9.9)$ \\
\hline 17 (19.7) & 4-methyl phenol & 85 (19.6) & $32(2.7)$ & $9(7.5)$ & $3(17.8)$ \\
\hline $18(20.9)$ & 4-ethyl phenol $\$$ & $3(0.7)$ & $2(0.2)$ & $4(3.3)$ & $1(6)$ \\
\hline 19 (21.9) & 2-amino acetophenone $\%$ & nd & nd & nd & $0.2(0.4)$ \\
\hline $20(23.4)$ & indole & nd & $1.1(0.2)$ & $0.8(0.6)$ & $0.1(0.5)$ \\
\hline 21 (23.7) & hexadecanoic acid & nd & nd & 9 (7.8) & $5(33)$ \\
\hline $22(24.2)$ & 3-methyl indole & $0.5(0.2)$ & $1.4(0.3)$ & $1.3(1.1)$ & $0.2(0.7)$ \\
\hline \multicolumn{6}{|c|}{ Total concentration of nonmethane VOCs } \\
\hline \multirow{2}{*}{\multicolumn{2}{|c|}{$\begin{array}{l}\text { identified in air }\left(\mu \mathrm{g} \mathrm{m}^{-3}\right) \\
\text { Percent of total peak area }(\%)\end{array}$}} & 806 & 1647 & 126 & 25 \\
\hline & & 82.3 & 99.5 & 65.9 & 92.4 \\
\hline
\end{tabular}

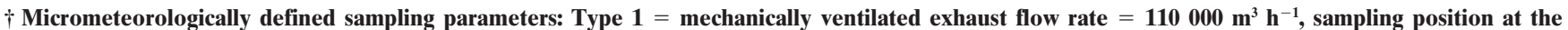
fan orifice; Type $2=39$-m-diam. basin, $z=$ ZINST $(0.1 \mathrm{~cm}$ roughness length, $1950 \mathrm{~cm}$ radius $=70 \mathrm{~cm}$ sampling height); Type $3=92-\mathrm{m}-$ diam. lagoon, $z=$ ZINST $(0.1 \mathrm{~cm}$ roughness length, $4600 \mathrm{~cm}$ radius $=189 \mathrm{~cm}$ sampling height); Type $4=$ a primary 100 -m-diam. photosynthetic lagoon, $z=$ ZINST $(0.1 \mathrm{~cm}$ roughness length, $5000 \mathrm{~cm}$ radius $=191 \mathrm{~cm}$ sampling height $)$.

+ USEPA priority pollutants identified in air samples: cresols (isomers and mixtures), $\mathrm{H}_{2} \mathrm{~S}$, phenol, and acetophenones. nd = analyte not detected.

kinetics and were characteristic of a receptor-ligand process. A qualitative analysis of VOCs present at sites representing the four classes of swine manure management systems is shown Fig. 3 and Table 3. The gas chromatography-flame ionization detector (GC-FID) chromatograms from deep pits or basins produced high odor intensities and relatively intense signal responses but were chemically simplistic in nature when compared with chromatograms from lagoons (Fig. 3; Table 3). These results provide evidence that chemical concentration rather than diversity is the largest determinate in the odor intensity response associated with swine manure odor. This observation is important since the ability to define odorant synergisms and antagonisms has been suggested to be the most significant obstacle in applying chemical methods in odor measurement (Mackie et al., 1998). Data presented in Fig. 2C provide evidence that the total air concentration of nonmethane VOCs can be used to predict the odor intensity associated with swine manure management systems evaluated in this study.

Odor measurement methods using human olfactory senses are based on the use of psychophysical theory. As the name implies, psychophysical methods are based on relationships between psychological and physical attributes of sensory stimuli. The intensity of olfactory stimuli reported by an individual is related to stimulus magnitude. For many odorants used in the food and fragrance industry, there is a linear relationship between $\log$ olfactory intensity reported by the individual and the air concentration of the odorant(s) present in air (Turk and Hyman, 1991). This relationship between perceived olfactory stimuli and intensity of sensation is referred to as the fundamental psychophysical law (Stevens, 1957, 1962). Data reported in Figure 2C show that the total air concentration of VOCs correlate well with the $\log$ stimulus intensity $\left(r^{2}=0.88\right)$ and therefore conform with the fundamental psychophysical law. In agreement with other olfactory studies, we observed that data quality was influenced by variables associated with the subjective nature of intensity scales, fatigue, sex, age, race, and visual cues (Cain et al., 1998; Degel and Koster, 1998; Liden et al., 1998; Livermore and Laing, 1998; Turk and Hyman, 1991). However, the use of the defined odor standard $\mathrm{Z} 2$ was found to reduce most of the sampling variability associated with intensity scales. Evidence for this conclusion was provided by the low average standard deviation reported by panelists for site evaluations (avg. std. dev. $=0.14$ odor units). A prerequisite that underlies all olfactory methods is the ability to define and properly sample chemical odorants that constitute a particular odor. Accomplishing this objective has been a formidable challenge, since it requires the use of both olfactory and analytical methods to validate sampling methods. The results of this study demonstrate utility of chemical methods in odor analysis 
Table 4. Mean horizontal flux rate and mean emission rate for analytes collected over a 24-h sampling period from swine manure management systems sampled in Table 3 and described in Table 5. Gas flux rates were measured using the theoretical profile shape micrometeorological method.

\begin{tabular}{|c|c|c|c|c|}
\hline \multirow[b]{2}{*}{ Parameter } & \multicolumn{4}{|c|}{ Swine manure management system type } \\
\hline & Type 1 & Type 2 & Type 3 & Type 4 \\
\hline $\begin{array}{l}\text { Mean wind velocity }\left(\mathrm{cm} \mathrm{s}^{-1}\right) \text { or ventilation rate }{ }^{\mathrm{b}}\left(\mathrm{m}^{3} \mathrm{~h}^{-1}\right) \\
\text { during sampling period }\end{array}$ & $110000^{b}$ & $190^{\mathrm{a}}$ & $128^{\mathrm{a}}$ & $90^{\mathrm{a}}$ \\
\hline Ammonia flux rate (ng $\left.\mathrm{NH}_{3} \mathrm{~cm}^{-2} \mathrm{~s}^{-1}\right)$ & $66 \dagger$ & 167 & 109 & 89 \\
\hline Ammonia emission rate $\left(\mathrm{g} \mathrm{NH}_{3}\right.$ system $\left.^{-1} \mathrm{~h}^{-1}\right)$ & 1060 & 1900 & 7700 & 6270 \\
\hline Methane flux rate ( $\left.\mathrm{ng} \mathrm{CH}_{4} \mathrm{~cm}^{-2} \mathrm{~s}^{-1}\right)$ & $34 \dagger$ & 178 & 218 & 200 \\
\hline Methane emission rate $\left(\mathrm{g} \mathrm{CH}_{4}\right.$ system $\left.^{-1} \mathbf{h}^{-1}\right)$ & 550 & 2010 & 15410 & 14120 \\
\hline Hydrogen sulfide flux rate $\left(\mathrm{ng} \mathrm{H}_{2} \mathrm{~S} \mathrm{~cm}^{-2} \mathrm{~s}^{-1}\right.$ ) & $0.37 \dagger$ & 1.10 & $\mathbf{0 . 3 2}$ & 0.24 \\
\hline Hydrogen sulfide emission rate $\left(\mathrm{g} \mathrm{H}_{2} \mathrm{~S}\right.$ system $\left.{ }^{-1} \mathrm{~h}^{-1}\right)$ & 5.9 & 12.5 & 22.7 & 16.9 \\
\hline Priority pollutant (PP) flux rate (ng $\left.\mathbf{P P} \mathrm{cm}^{-2} \mathrm{~s}^{-1}\right) \uparrow$ & $1.04 \dagger$ & 2.30 & 0.56 & 0.30 \\
\hline Priority pollutant emission rate (g PP system $\left.{ }^{-1} \mathbf{h}^{-1}\right) \%$ & 16.6 & 26.1 & 39.6 & 20.9 \\
\hline Volatile organic compound flux rate (ng VOC $\left.\mathrm{cm}^{-2} \mathrm{~s}^{-1}\right)$ & $5.60 \dagger$ & 35.0 & 1.60 & 0.21 \\
\hline VOC emission rate (g VOC system ${ }^{-1} h^{-1}$ ) & 89.9 & 394.0 & 113.1 & 14.5 \\
\hline Total air pollutant emission rate (g TAP system $\left.{ }^{-1} h^{-1}\right)$ & 1720 & 2420 & 15550 & 14150 \\
\hline
\end{tabular}

$\dagger$ System flux rate calculated using an active surface area of $4459000 \mathrm{~cm}^{2}$ and assumes a homogenous emitting source for active surfaces.

\$ USEPA priority pollutants identified in air samples: cresols (isomers and mixtures), hydrogen sulfide, phenol, and acetophenones.

and in the validation of air sample collection methods (i.e., Teflon bag sampling).

\section{Emission Rate of Air Pollutants from Swine Manure Management Systems}

Analysis of $\mathrm{CH}_{4}$ emission rates, airborne VOC concentration, and odor intensity for the 29 swine manure management systems evaluated in this study indicated that manure management systems could be functionally classified according to the ratio of $\mathrm{P}$ to $\mathrm{S}$ concentrations. This analysis, however, provided limited insight into the differences in microbial processes associated with these systems. In an effort to further elucidate chemical and biological differences associated with the system classification, a detailed evaluation of effluent characteristics and gases $\left(\mathrm{H}_{2} \mathrm{~S}, \mathrm{NH}_{3}, \mathrm{CH}_{4}, \mathrm{VOCs}\right)$ was conducted at four swine manure management systems that represented each of the four system classes. Each of the swine manure management systems chosen for the follow-up study were shown to exhibit the same relative profiles in $\mathrm{CH}_{4}$ emission rate regardless of the flux measurement strategy employed (Table 1, chamber-based vs. Table 4, micrometeorological-based). These results provided additional support that manure management loading parameters influenced bioconversion efficiency. In systems with relatively low emission rates of $\mathrm{CH}_{4}$ and $\mathrm{NH}_{3}$ (Type 1 and 2 systems, Tables 3, 4, and 5), high concen- trations of organic carbon and nitrogen (particulate C, $\mathrm{H}, \mathrm{N}$ ) were found to accumulate in the solution phase (Table 1). These systems were also observed to have the highest odor intensities. In contrast, Type 3 and 4 systems showed a lower tendency to accumulate effluent organic material (Fig. 3; Tables 1 and 3) and a much higher emission rate of $\mathrm{CH}_{4}$ (Fig. 2; Table 1).

The emission rate of hydrogen sulfide $\left(\mathrm{H}_{2} \mathrm{~S}\right)$ appeared to be independent of the manure management system classification developed in this study (Table 5). This observation was unexpected since the emission rates of $\mathrm{CH}_{4}, \mathrm{NH}_{3}$, and VOCs were dependent upon the type of manure management system used (Fig. 2; Table 5). Common precursors of $\mathrm{H}_{2} \mathrm{~S}$ in anaerobic swine manure management systems may include cysteine (cystine), methionine (indirect biotransformation), sulfur $\left(\mathrm{S}_{0}\right)$, thiosulfate $\left(\mathrm{S}_{2} \mathrm{O}_{3}\right)$, or sulfate $\left(\mathrm{SO}_{4}\right)$. Sulfate $\left(\mathrm{SO}_{4}\right)$ is known to play a major role in mammalian physiology and is released ( 0.1 to $1.4 \mathrm{~g}$ of $\mathrm{SO}_{4} \mathrm{~d}^{-1}$ ) in urinary excretions as $\mathrm{SO}_{4}$-organic conjugates or $\mathrm{SO}_{4}$ salts (Lehninger, 1988, p. 703). Based on a daily $\mathrm{SO}_{4}$ excretion rate of $0.13 \mathrm{~g} \mathrm{SO}_{4} \mathrm{pig}^{-1} \mathrm{~d}^{-1}$ and a complete conversion to $\mathrm{H}_{2} \mathrm{~S}$, a production facility with 4560 pigs (Site A, Table 5) is estimated to emit $593 \mathrm{~g} \mathrm{H}_{2} \mathrm{~S} \mathrm{~d}^{-1}$ through dissimilatory $\mathrm{SO}_{4}$ reduction processes (Gottschalk, 1988; Postgate, 1984). This calculated value is similar to the observed daily $\mathrm{H}_{2} \mathrm{~S}$ emission rate (Table 5, Site A),

Table 5. Emission rates for air pollutants collected over a 24-h sampling period from swine manure management systems sampled in Tables 3 and 4. Values were calculated from flux measurements that employed the theoretical profile shape micrometeorological method.

\begin{tabular}{|c|c|c|c|c|}
\hline \multirow[b]{2}{*}{ Parameter } & \multicolumn{4}{|c|}{ Swine manure management system type } \\
\hline & Type $1 \%$ & Type 2 & Type 3 & Type 4 \\
\hline Annual production number and type & $\begin{array}{l}\text { Feeder to finish, } \\
13680 \text { animals } \mathrm{yr}^{-1}\end{array}$ & $\begin{array}{l}\text { Farrow to finish, } \\
8200 \text { animals } \mathrm{yr}^{-1}\end{array}$ & $\begin{array}{l}\text { Feeder to finish, } \\
14170 \text { animals } \mathrm{yr}^{-1}\end{array}$ & $\begin{array}{l}\text { Farrow to feeder, } \\
18500 \text { animals } \mathrm{yr}^{-1}\end{array}$ \\
\hline Site manure management system description $\dagger$ & 4, DP & 2, CLB; 2, PP & 1, L; PFS $\div$ & 2, PL; PFS $\div$ \\
\hline Ammonia emission $\left(\mathrm{kg} \mathrm{NH_{3 }}\right.$ site $\left.^{-1} \mathrm{~d}^{-1}\right)$ & 101.7 & 141.7 & 232.8 & 369.2 \\
\hline Methane emission ( $\mathrm{kg} \mathrm{CH} \mathrm{CH}_{4}$ site $^{-1} \mathrm{~d}^{-1}$ ) & 52.8 & 122.7 & 466.1 & 831.0 \\
\hline Hydrogen sulfide emission $\left(\mathrm{kg} \mathrm{H}_{2} \mathrm{~S}\right.$ site $\left.^{-1} \mathrm{~d}^{-1}\right)$ & 0.6 & 0.9 & 0.7 & 1.0 \\
\hline Priority pollutant (PP) emission (kg PP site ${ }^{-1} \mathbf{d}^{-1}$ ) & 1.6 & 2.1 & 1.2 & 1.2 \\
\hline Volatile organic compound emission $\left(\mathrm{kg}\right.$ VOC site $\left.{ }^{-1} \mathbf{d}^{-1}\right)$ & 8.6 & 23.2 & 3.4 & 0.9 \\
\hline Combined total air pollutant emission $\left(\mathrm{kg}\right.$ TAP $\left.\operatorname{site}^{-1} \mathrm{~d}^{-1}\right)$ & 165 & 291 & 704 & 1203 \\
\hline
\end{tabular}

$\dagger$ Manure storage system description: $\mathbf{P L}=$ phototrophic lagoon; $\mathbf{P F S}=$ continuous pit flush system; $\mathbf{L}=$ lagoon; $\mathbf{E B}=$ earthen basin; $\mathbf{C L B}=\mathbf{c o n c r e t e}-$ lined basin (outdoor); $\mathbf{D P}=$ deep pit; $\mathbf{P P}=$ pull-plug.

\$ The emission rate for analytes released from the continuous pit flush systems was calculated based on the flux rates (Table 4 ) and the total pit surface area actively flushed with recycled lagoon liquid. The active surface area for PFS systems at Sites 3 and 4 was 510 and 890 m², respectively. 
indicating that urinary $\mathrm{SO}_{4}$ excretions may account for a significant proportion of the sulfur (S) precursors contributing to the $\mathrm{H}_{2} \mathrm{~S}$ emissions measured in this study. The finding that $\mathrm{SO}_{4}$ may be the major $\mathrm{S}$ precursor contributing to $\mathrm{H}_{2} \mathrm{~S}$ emissions provides microbiological insight into why $\mathrm{H}_{2} \mathrm{~S}$ emissions might be independent of manure management system classification. All complex, organic forms of sulfur $(\mathrm{S})$ require energy expenditure to produce volatile, S-containing gases (i.e., formation of methyl mercaptan or dimethyl disulfide from methionine; Gottschalk, 1988). Energy-consuming microbial processes have been shown to be highly sensitive to effluent environmental parameters such as metal ion concentration and concentration of organic matter (Oleszkiewicz and Sharma, 1990; Hill and Bolte, 1989). In contrast, $\mathrm{SO}_{4}$ reduction is an energy-yielding process that is highly favorable under environmental conditions observed in all manure management systems evaluated in this study. These results suggest that future massbalance studies should aim at characterization of the $\mathrm{S}$ cycle in swine manure management systems with special emphasis on sources and fate of $\mathrm{SO}_{4}$.

Manure management systems with high loading rates and relatively low $\mathrm{CH}_{4}$-producing activity showed up to a 26-fold increase in total VOC emissions when compared with low-odor photosynthetic lagoons (Fig. 2 and Table 5). The data indicate that VOCs are more likely to be of concern with systems employing high loading rates, while $\mathrm{CH}_{4}$ and $\mathrm{NH}_{3}$ are likely to be more problematic with systems employing lower loading rates. In addition to nuisance concerns, elevated VOC concentrations may present a concern to human health. A small number of regulated industrial pollutants are present in airborne emission streams from swine production facilities (Table $3)$. The air concentrations for these compounds at the source were found to be at least one order of magnitude below exposure levels established for safe work environments by occupational health organizations (Plog, 1988, p. 770-783). However, the use of industrial exposure indices may not be appropriate for assessing exposure to animal waste emissions due to the following considerations. First, several agricultural waste pollutants are unique to agricultural systems and thus have no established exposure indices. Second, bioactive airborne pollutants, such as microbial secondary metabolites, remain largely uncharacterized from swine production systems. Bioactive compounds have been identified as a serious human health risk, since many of these compounds have been shown to influence mammalian cell physiology in the part per billion and sub-part per billion range (Andersson et al., 1998). Third, there is a lack of information on the acute and chronic toxicological effects of VOCs derived from swine manure on children and individuals of compromised health. This concern is reflected in recent epidemiological studies that have shown a higher incidence of psychological dysfunction and health-related problems in individuals residing near large-scale swine production facilities (Thu et al., 1997; Schiffman et al., 1995).

Ammonia emissions from the four intensively studied swine production systems were found to violate release reporting requirements for $\mathrm{NH}_{3}$ under the USEPA Comprehensive Environmental Response, Compensation, and Liability Act (CERCLA) (USEPA, 2000). Emergency Planning and Community Right-to-Know Act (EPCRA) Section 329(4) defines facility to include stationary structures on a single site, or on contiguous or adjacent sites owned or operated by the same person. Under this definition, the aggregated emission rate of registered hazardous substances (i.e., $\mathrm{NH}_{3}, \mathrm{H}_{2} \mathrm{~S}$, VOC, particulate matter) from all swine production facility point sources is subject to release reporting requirements. The current reporting requirements for $\mathrm{NH}_{3}$ (and $\mathrm{H}_{2} \mathrm{~S}$ ) are set at $100 \mathrm{lb}$ (about $45 \mathrm{~kg}$ ) of $\mathrm{NH}_{3} \mathrm{~d}^{-1}$ (USEPA, 2000). The range for $\mathrm{NH}_{3}$ emissions from the four intensively studied swine production sites ranged from 101.7 $\mathrm{kg} \mathrm{NH}_{3} \mathrm{~d}^{-1}\left(224 \mathrm{lb} \mathrm{NH}_{3} \mathrm{~d}^{-1}\right)$ to $369.2 \mathrm{~kg} \mathrm{NH}_{3} \mathrm{~d}^{-1}$ (813.9 lb NH $\mathrm{N}_{3} \mathrm{~d}^{-1}$ ). The observed aggregate emission rates for swine production facilities evaluated in this study exceed the CERCLA reporting requirements for $\mathrm{NH}_{3}$ by 55 to $88 \%$. Under Section 304 of EPCRA, the "owner or operator" of a facility is required to report immediately to the appropriate state emergency response commissions and local emergency planning committees when there is a release of a CERCLA hazardous substance. The results indicate that $\mathrm{NH}_{3}$ emissions from swine production facilities have the potential to exceed release reporting requirements enforced by the USEPA.

Lagoons with established anoxic bacterial photosynthetic populations (Type 4 systems; bacteriochlorophyll

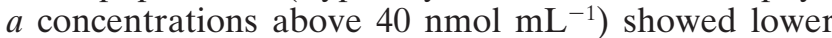
odor intensities, lower air concentrations of VOCs, and lower emission rates of VOCs when compared with other swine manure management systems (Fig. 3; Tables 3 and 4). Photosynthetic bacteria carry out the process of photosynthesis under anaerobic conditions. These requirements for photosynthesis differ greatly from algae and plant species that use water as an electron source for photosystem II and evolve oxygen in this reaction (Kobayashi and Kobayashi, 1995). Instead of using water as a reductant, anoxic photosynthesis is dependent on substrates such as $\mathrm{H}_{2} \mathrm{~S}$, hydrogen $\left(\mathrm{H}_{2}\right)$, and VOCs to provide reducing equivalents, while light from the sun provides the energy source (Gottschalk, 1988). Bacteria capable of anoxic photosynthesis are categorized into one of four major groups (purple sulfur, purple nonsulfur, green sulfur, and green-gliding) based on the presence of specific types of bacteriochlorophyl, phylogenetic characteristics, and metabolic capabilities (Gottschalk, 1988; Siefert et al., 1978). All four groups of photosynthetic bacteria are able to utilize organic substrates (VOCs) as a source of carbon and the greengliding and purple bacteria are able to use organic substrates as proton donors. However, a novel species of Rhodobacter (Rhodobacter sp. PS9) dominates the photosynthetic population (about $20 \%$ of the total microbial community structure) in all photosynthetic swine lagoon systems examined in this study (Do et al., 1998, 1999). The physiological characteristics of this purple nonsulfur photosynthetic bacterium provide evidence for the observed degradation of VOCs and decreased odor emissions from photosynthetic swine waste lagoons. 


\section{CONCLUSIONS}

The lack of knowledge concerning functional aspects of swine manure management systems has complicated present efforts to develop or improve emission abatement technologies to meet the stringent air quality and nuisance regulations presently imposed by several states. The task of elucidating functional aspects of swine manure management systems is often convoluted by the plethora of manure management strategies presently used in the swine industry. In the absence of appropriate compatibility or functional measures, emission abatement strategies are often paired with swine manure management systems based only on empirical observations. As a result, the performance of these abatement methods is difficult to predict and often impossible to improve through scientific methods. Effluent concentrations of $\mathrm{P}$ and $\mathrm{S}$ are shown in this study to be a useful tool in the classification of swine manure management systems according to functional aspects of the system. The methods described in this study provide an inexpensive means to rapidly assess best management practices for swine manure management systems and also provide a means by which to identify swine production systems that represent a potential air quality or nuisance concern.

\section{ACKNOWLEDGMENTS}

Research support from the National Pork Producers Council (to J.A. Zahn, A.A. DiSpirito, and J.L. Hatfield), Iowa State University (ISU) Office of Biotechnology (to A.A. DiSpirito), and from the USDA-ARS (to J.A. Zahn, and J.L. Hatfield) is gratefully acknowledged. The assistance of Mr. Tim Hart (National Soil Tilth Laboratory [NSTL]) with data collection, Ms. Lori Merrill (ISU) with manure dry weight analysis, and Mr. Pierce Fleming (NSTL) and Dr. David Laird (NSTL) with ICP-AES analysis is kindly acknowledged. The informative discussions with Dr. John Prueger (NSTL) concerning application of meteorological approaches in measurement of evaporative fluxes is also acknowledged. A special thanks is extended to the following site collaborators for their valuable contributions in site selection and for allowing access to sites: Dr. Thomas Sauer (USDA Biomass Res. Ctr., Univ. of Arkansas), Mr. James Seward and Joe Locke (Tyson Foods, Springdale, AR), Mr. Brent Rastetter (Heartland Pork, Alden, IA), Mr. Alan Witt (Murphy Family Farms, Algona, IA), Dr. Matias Vanotti and Dr. Patrick Hunt (USDA Costal Plains Soil, Water, and Plant Res. Center, Florence, SC), Mr. Brent Roberts (Monsanto, EnviroChem Systems Division, St. Louis, MO), and Mr. Alan Junck, (Junck Farms, Ogden, IA).

\section{REFERENCES}

American Society of Agricultural Engineers. 1988. Manure production and characteristics. ASAE D384.1. ASAE, St. Joseph, MI.

Andersson, M.A., R. Mikkola, R.M. Kroppenstedt, F.A. Rainey, J. Peltola, J. Helin, K. Sivonen, and M.S. Salkinoja-Salonen. 1998 The mitochondrial toxin produced by Streptomyces griseus strain isolated from an indoor environment is valinomycin. Appl. Environ. Microbiol. 64:4767-4773.

Asman, W.A.H. 1995. Ammonia and ammonium in the atmosphere: Present knowledge and recommendations for further research. p. 55-70. In G.J. Heij and J.W. Erisman (ed.) Acid rain research: Do we have enough answers? Proc. of a Speciality Conf., 's-Hertogenbosch, the Netherlands. 10-12 Oct. 1994. Elsevier Science B.V., Amsterdam, the Netherlands.

Cain, W.S., R. Wijk, C. Lulejian, F. Schiet, and lai-Chu See. 1998.
Odor identification: Preceptual and semantic dimensions. Chem. Senses 23:309-326.

CEM Corporation. 1996. Methods for microwave digestion of environmental samples. CEM Corp., Mathews, NC.

Chan, A.S.K., J.H. Prueger, and T.B. Parkin. 1998. Comparison of closed-chamber and bowen-ratio methods for determining methane flux from peatland surfaces. J. Environ. Qual. 27:232-239.

Degel, J., and E.P. Koster. 1998. Implicit memory for odors: A possible method for observation. Percept. Motor Skills 86:943-952.

Deppenmeier, U., V. Muller, and G. Gottschalk. 1996. Pathways of energy conservation in methanogenic archaea. Arch. Microbiol. 165:149-163.

DiSpirito, A.A., Y.S. Do, C.L. Krema, J. Emerson, and J.A. Zahn 1995. Methods to monitor microbial populations and odors from livestock wastes. p. 80-85. In Proc. of the Int. Livestock Odor Conf., Iowa State Univ., Ames. 16-18 Oct. 1995. Iowa State Univ. College of Agric., Ames.

DiSpirito, A.A., and J.A. Zahn. 1999. Device for quantitation of odors from liquid livestock wastes. U.S. Patent 5766 551. Date issued: 27 April.

Do, T.S., D.H. Buckley, T.M. Schmidt, and A.A. DiSpirito. 1999 Isolation and characterizations of a new species of Rhodobacter, Rhodobacter PS9, and their role in odor remediation in anaerobic swine waste lagoons. Abstract Q-7. p. 423. In General Meeting Am. Soc. for Microbiol. ASM, Washington, DC.

Do, T.S., J.A. Zahn, L. Merrill, L. Halverson, J. McKinney, and A.A. DiSpirito. 1998. Odor remediation in anaerobic livestock waste lagoons using phototrophic bacteria. Abstract Q-7. p. 423. In General Meeting Am. Soc. for Microbiol. ASM, Washington, DC.

Fenchel, T., and B.J. Finlay. 1994. Evolution of life without oxygen. Am. Sci. 82:22-29.

Giusquiani, P.L., L. Concezzi, M. Businelli, and A. Macchioni. 1998. Fate of pig liquid fraction in calcareous soil: Agricultural and environmental implications. J. Environ. Qual. 27:364-371.

Gottschalk, G. 1988. Bacterial metabolism. 2nd ed. Springer-Verlag, New York.

Harkin, T. 1997. Animal waste pollution in America: An emerging national problem. Report compiled by the minority staff of the United States Senate Committee on Agriculture, Nutrition, and Forestry, Washington, DC [Online]. Available at www.senate.gov/ agriculture/animalw.htm (verified 9 Nov. 2000).

Harper, L.A., and R.R. Sharpe. 1997. Climate and water effects on gaseous ammonia emissions from a swine lagoon. p. 223-229. In L.M. Risse (ed.) Proc. of the Southwestern Sustainable Animal Waste Management Workshop, Tifton, GA. 11-13 Feb. 1997. Univ. of Georgia Publ. no. ENG97-001. Agric. Eng. Dep., Univ. of Georgia, Athens, GA.

Hill, D.T., and J.P. Bolte. 1989. Digester stress as related to isobutyric and isovaleric acids. Biol. Wastes 28:33-37.

Hobbs, P.J., T.H. Misselbrook, and B.F. Pain. 1995. Assessment of odours from livestock wastes by a photoionization detector, an electronic nose, olfactometry and gas chromatography-mass spectrometry. J. Agric. Eng. Res. 60:137-144.

Jacobson, L.D., C.J. Clanton, C. Radman, D. Schmidt, R. Nicalai, and K.A. Janni. 1997a. Comparsion of hydrogen sulfide and odor emissions from animal manure storages. p. 404-412. In J.A.M. Voermans and G.J. Monteny (ed.) Proc. of the Int. Symp. on Animal and Odor Control from Animal Production Facilities, Vinkeloord, the Netherlands. 6-10 Oct. 1997. Dutch Soc. of Agric. Eng., Vinkeloord, the Netherlands.

Jacobson, L.D., C. Radman, D. Schmidt, and R. Nicalai. 1997b. Odor measurements from manure storages on Minnesota pig farms. $p$. 93-100. In Proc. of TLES, Bloomington, MN. 29-31 May. Am. Soc. Agric. Eng., St. Joseph, MI.

Japenga, J.J., and K. Harmsen. 1990. Determination of mass balances and ionic balances in animal manure. Neth. J. Agric. Sci. 38: 353-367.

Kobayashi, M., and M. Kobayashi. 1995. Waste remediation and treatment using anoxygenic phototrophic bacteria. p. 1269-1282. In R.E. Blankenship et al. (ed.) Anoxygenic photosynthetic bacteria. Kluwer Academic Publ., Boston, MA.

Lana, R.P., J.B. Russell, and M.E. Amburgh. 1998. The role of $\mathrm{pH}$ in regulating ruminal methane and ammonia production. J. Anim. Sci. 76:2190-2196. 
Lehninger, A.L. 1988. Principles of biochemistry. Worth Publ., New York.

Liden, E., S. Nordin, L. Hogman, A. Ulander, F. Deniz, and A.G. Gunnarsson. 1998. Assessment of odor annoyance and its relationship to stimulus concentration and odor intensity. Chem. Senses 23:113-117.

Livermore, A., and D.G. Laing. 1998. The influence of chemical complexity on the perception of multicomponent odor mixtures. Percept. and Psychophys. 60:650-661.

MacIntyre, S., R. Wanninkhof, and J.P. Chanton. 1995. Trace gas exchange across the air-water interface in freshwater and coastal marine environments. p. 52-97. In P.A. Matson and R.C. Harriss (ed.) Biogenic trace gases: Measuring emissions from soil and water. Methods in Ecology. Blackwell Science, Cambridge, MA.

Mackie, R.I., P.G. Stroot, and V.H. Varel. 1998. Biochemical identification and biological origin of key odor components in livestock waste. J. Anim. Sci. 76:1331-1342.

Majewski, M.S. 1990. Field methods comparisons for estimating evaporative flux densities of pesticides from fallow soil. Order Number 9110651. UMI Diss. Services, Ann Arbor, MI.

Majewski, M.S., D.E. Glotfelty, and J.N. Seiber. 1989. A comparison of the aerodynamic and the theoretical-profile shape methods for measuring pesticide evaporation from soil. Atmos. Environ. 23:929-938.

Miner, J.R. 1982. Controlling odors from livestock production facilities. p. 30-35. In R.J. Smith (ed.) Research results in manure digestion, runoff, refeeding, odors. North Central Regional Res. Publ. no. 284. Midwest Plan Service, Iowa State Univ., Ames.

Miner, J.R. 1995. An executive summary: A review on the literature on the nature and control of odors from pork production facilities. National Pork Producers Council, Des Moines, IA.

Miner, J.R. 1999. Alternatives to minimize the environmental impact of large swine production units. J. Anim. Sci. 77:440-444.

Obrock-Hegel, C.E. 1997. The effects of reducing dietary crude protein concentration on odor in swine facilities. M.S. thesis. Univ. of Nebraska, Lincoln.

Oleszkiewicz, J.A., and V.K. Sharma. 1990. Stimulation and inhibition of anaerobic processes by heavy metals: A review. Biol. Wastes 31:45-67.

Pain, B.F., V.R. Phillips, C.R. Clarkson, T.M. Misselbrook, Y.J. Rees, and J.W. Farrent. 1990. Odor and ammonia emissions following spreading of aerobically-treated pig slurry on grassland. Biol. Wastes 34:149-160.

Plog, B.A. 1988. Fundamentals of industrial hygiene. National Safety Council, Chicago, IL.

Postgate, J.R. 1984. The sulfate reducing bacteria. Cambridge Univ. Press, New York.

Powers, W.J., H.H. Van Horn, A.C. Wilkie, C.J. Wilcox, and R.A. Nordstedt. 1999. Effects of anaerobic digestion and additives to effluent or cattle feed on odor and odorant concentration. J. Anim. Sci. 77:1412-1421.

Safley, Jr., L.M., M.E. Casanda, J.W. Woodbury, and K.F. Roos. 1992. Global methane emissions from livestock and poultry manure. USEPA, Washington, DC.

Sauer, P.J., and J.L. Hatfield. 1994. Walnut creek watershed research protocol report. National Soil Tilth Lab. Bull. 94-1. USDA-ARS, Ames, IA.

SAS Institute. 1998. JMP. SAS Inst., Cary, NC.

Schiffman, S.S., E.A. Sattely Miller, M.S. Suggs, and B.G. Graham. 1995. The effect of environmental odors emanating from commercial swine operations on the mood of nearby residents. Brain Res. Bull. 37:369-375.
Schulte, D.D., D.A. Kottwitz, and C.B. Gilbertson. 1985. Nitrogen content of scraped swine manure. p. 321-328. In Proc. of the 5th Int. Symp. on Agric. Waste, Chicago, IL. 16-17 Dec. 1985. ASAE, St. Joseph, MI.

Sharpe, R.R., and L.A. Harper. 1997. Atmospheric methane emissions from a swine lagoon. p. 237-241. In L.M. Risse (ed.) Proc. of the Southwestern Sustainable Animal Waste Management Workshop, Tifton, GA. 11-13 Feb. 1997. Univ. of Georgia Publ. no. ENG97001. Agric. Eng. Dep., Univ. of Georgia, Athens, GA.

Sharpe, R.R., and L.A. Harper. 1998. Ammonia and nitrous oxide emissions from sprinkler irrigation applications of swine effluent. J. Environ. Qual. 26:1703-1706.

Siefert, E., R.L. Irgens, and N. Pfennig. 1978. Phototrophic purple and green bacteria in a sewage treatment plant. Appl. Environ. Microbiol. 35:38-44.

Simpson, I.J., G.W. Thurtell, G.E. Kidd, M. Lin, T.H. DemetriadesShaw, I.D. Flitcroft, E.T. Kanemasu, D. Nie, K.F. Bronson, and H.U. Neue. 1995. Tunable diode laser measurements of methane fluxes from an irrigated rice paddy field in the Philippines. J. Geophys. Res. 100(D4):7283-7290.

Stevens, S.S. 1957. On the psychophysical law. Psychol. Rev. 64: $153-181$.

Stevens, S.S. 1962. The surprising simplicity of sensory metric. Am. Psychol. 17:29-39.

Thu, K., K. Donham, R. Ziegenhorn, S.J. Reynolds, P.S. Thorne, P Subramanian, W. Whitten, and J. Stookesberry. 1997. A control study of health and quality of life of life of residents living in the vicinity of large scale swine production facilities. J. Agric. Health Safety 3:13-26.

Turk, A., and A.M. Hyman. 1991. Odor measurement and control p. 842-881. In G.D. Clayton and F.L. Clayton (ed.) Patty's industrial hygiene and toxicology. John Wiley \& Sons, New York.

USEPA. 1979. Methods for chemical analysis of water and wastes. USEPA Rep. 600/4-79-020. USEPA EMSL, Cincinnati, OH.

USEPA. 2000. Comprehensive Environmental Response, Compensation, and Liability Act [Online]. Available at http://www.epa.gov/ oerrpage/superfund/action/law/cercla.htm (verified 9 Nov. 2000).

VanWicklen, G.L. 1997. Air quality in confinement animal facilities. p. 231-236. In L.M. Risse (ed.) Proc. of the Southwestern Sustainable Animal Waste Management Workshop, Tifton, GA. 11-13 Feb. 1997. Univ. of Georgia Publ. no. ENG97-001. Univ. of Georgia Publ. no. ENG97-001. Agric. Eng. Dep., Univ. of Georgia, Athens, GA.

Wilson, J.D., G.W. Thurtell, G.E. Kidd, and E.G. Beauchamp. 1982. Estimation of the rate of gaseous mass transfer from a surface source plot to the atmosphere. Atmos. Environ. 16:1861-1867.

Zahn, J.A. 1997. Swine odor and emissions from pork production. p. 20-122. In K. McGuire (ed.) Environmental assurance program. National Pork Producers Council, Des Moines, IA.

Zahn, J.A., and A.A. DiSpirito. 2000. Composition and use of a swine odor standard in quantitation of swine odors. ISURF \#2574. United States Patent and Trademark Office, Washington, DC. Patent pending.

Zahn, J.A., A.A. DiSpirito, Y.S. Do, B.E. Brooks, E.E. Cooper, and J.L. Hatfield. 2001. Correlation of human olfactory responses to airborne concentrations of malodorous volatile organic compounds emitted from swine effluent. J. Environ. Qual. 30:624-634 (this issue).

Zahn, J.A., J.L. Hatfield, Y.S. Do, A.A. DiSpirito, D.A. Laird, and R.L. Pfeiffer. 1997. Characterization of volatile organic emissions and wastes from a swine production facility. J. Environ. Qual. 26:1687-1696. 